\title{
"Nothing We Say Matters": Teague and New Rules
}

\author{
Linda Meyer $\dagger$
}

Off in a corner of habeas corpus doctrine, the Supreme Court is quietly eroding the foundation of common law adjudication. The Court is wearing away the power of precedent itself, stripping prior cases of all persuasive force beyond their particular factual contexts. Limited to its facts, a case will guide future cases only in the extraordinary event that history repeats itself. The analogical links forged between past and present, from one case to the next, stand broken. In such a setting, judges simply decide by fiat, without guidance from rules or cases. The Court is forced to the irony of saying, "Nothing we say matters."

This is the dramatic implication to be drawn from the line of cases following Teague $v$ Lane, which introduced the sweeping rule that "new" constitutional law would be neither announced nor applied in federal habeas corpus cases. ${ }^{1}$ This rule of nonretroactivity is exceptional. Ordinarily, a court reaches the merits of the question brought before it and applies its resolution to the parties, even though their dispute arose in the past. In other words, judicial decisions are usually retroactive, at least in the sense that they do not just apply to events in the future, but also to events in the past. Most of the time, this modest retroactivity is not a problem. A new decision does not disturb previously decided cases because the doctrine of res judicata prevents a second

† Assistant Professor, Vanderbilt Law School. This article was supported by a Vanderbilt Summer Research Grant, for which I thank Dean John Costonis. For their support and insightful comments, I thank John Applegate, Stuart Banner, Rebecca Brown, Dean John Costonis, Barry Friedman, Susan Kay, Nancy King, Ken Kress, Lynn Lopucki, John Marshall, Tom McCoy, Trisha Olson, Bob Rasmussen, and Nick Zeppos. I also wish to applaud the spectacular efforts of my research assistants, Audrey Nacamuli and Jeff Pettit. Special thanks go to Jeff Meyer, who read many, many drafts and provided many, many words of help and encouragement.

1489 US 288, 310, 316 (1989) (plurality opinion). The Supreme Court has applied Teague only to state convictions, but some circuits have also applied Teague to federal convictions. See Markus Dirk Dubber, Prudence and Substance: How the Supreme Court's New Habeas Retroactivity Doctrine Mirrors and Affects Substantive Constitutional Law, 30 Am Crim L Rev 1, 10-11 (1992). 
look even if an evolution of doctrine renders old adjudications obsolete.

Not so for criminal convictions. The federal habeas corpus statute allows a state prisoner to attack his conviction in federal court at any time. ${ }^{2}$ To prevent prisoners from endlessly attacking long-stale convictions on the basis of new constitutional decisions, Teague limits state prisoners to the law in effect at the time their convictions were final. A prisoner cannot ask for or take advantage of "new rules." A plurality of the Court in Teague reasoned that convictions should not be overturned on the basis of constitutional violations that state courts could not have known of, let alone avoided, at the time a case was tried. ${ }^{4}$

This seemingly sensible result has foundered on an apparently insoluble problem: how to define a "new rule." Teague defined a "new rule" as any rule not "dictated by precedent existing at the time the prisoner's conviction became final. ${ }^{.5}$ In cases following Teague, the Court has strictly defined "dictated" as that which is compelled as a matter of logical deduction from the holding of a precedent. At the same time, in the common law tradition, the Court has declined to limit the "holding" of a precedent to any explicit statement of a rule in the language of that case. Instead, a holding includes the "material" facts and result of the prior case, and the appropriate level of generality at which to capture and to describe those material facts is not predetermined by anything the prior court has said.

As a result, the "dictated by precedent" test becomes virtually impossible to satisfy. Without any duty to follow the explicit statement of a rule in a prior case, a court can easily find that the patchwork of facts in a prior case does not "dictate" or logically compel the disposition of a different patchwork of facts in the instant case. Because a factual distinction can always be found, the prisoner is always asking for a "new" rule.

Under Teague's jurisprudence, not only does the prisoner lose-so does the process of adjudication itself. In the first place, when the Court says that the statement of a rule in a prior case does not "dictate," it calls into question its own authority to announce and articulate binding rules of law. Lower courts need

2 See 28 USC § 2254 (1988).

3 Teague, 489 US at 309 ("Application of constitutional rules not in existence at the time a conviction became final seriously undermines the principle of finality which is essential to the operation of our criminal justice system.").

${ }^{4}$ Id at 309-10.

5 Id at 301. 
not follow the rules as they are articulated if they can distinguish a case on its facts.

In the second place, by focusing only on what is "dictated" by past cases, the Court destabilizes the process of common law adjudication. Common law reasoning does not deduce results from previously established rules. Instead, it analogizes from one set of facts to another. Analogies are suggestive, but they are never logically compelling because any case will be somewhat like others and somewhat different-never identical. Teague's insistence that any rule not deducible from prior cases is "new" means that the subtle analogical links between past and present cases no longer count. They are not strong enough to "dictate" a precise outcome. Under Teague, all cases decided by analogy are "new" and therefore an unfair surprise to litigants and state courts.

Predictably, Teague has come under heavy fire from law review commentators. Surprisingly, however, most commentators have targeted Teague only at a legal policy level, criticizing its effect on the rights of prisoners and its alteration of federal/state relations. ${ }^{6}$ To date, no commentators have systematically turned

- Many commentators note that Teague has severely diminished the rights of state habeas corpus petitioners. See, for example, Ann Woolhandler, Demodeling Habeas, 45 Stan L Rev 575, 638-44 (1993); Dubber, 30 Am Crim L Rev at 25-33 (cited in note 1); Marshall J. Hartman, To Be or Not to Be a New Rule: The Non-Retroactivity of Newly Recognized Constitutional Rights After Conviction, 29 Cal W L Rev 53, 81-82 (1992); Barry Friedman, Habeas and Hubris, 45 Vand L Rev 797, 800-01, 819-28 (1992); Kit Kinports, Habeas Corpus, Qualified Immunity, and Crystal Balls: Predicting the Course of Constitutional Law, 33 Ariz L Rev 115, 175-81, 196-97 (1991); Richard H. Fallon, Jr. and Daniel J. Meltzer, New Law, Non-Retroactivity, and Constitutional Remedies, 104 Harv L Rev 1731, 1748-49 (1991); David R. Dow, Teague and Death: The Impact of Current Retroactivity Doctrine on Capital Defendants, 19 Hastings Const L Q 23, $49-50$ (1991); Kathleen Patchel, The New Habeas, 42 Hastings L J 939, 1051 (1991); Yale L. Rosenberg, Kaddish for Federal Habeas Corpus, 59 Geo Wash L Rev 362, 367-71, 373-74 (1991); Note, Federal Habeas Corpus: The New Standard of Retroactivity, 57 Brooklyn L Rev 865, 876, 890-94 (1991); Paul J. Heald, Retroactivity, Capital Sentencing, and the Jurisdictional Contours of Habeas Corpus, 42 Ala L Rev 1273, 1273 (1991); Ann Althouse, Saying What Rights Are-In and Out of Context, 1991 Wis L Rev 929, 944, 966; Steven M. Goldstein, Chipping Away at the Great Writ: Will Death Sentenced Federal Habeas Corpus Petitioners Be Able to Seek and Utilize Changes in the Law?, 18 NYU Rev L \& Soc Change 357, 363 (1990-91); James S. Liebman, More Than "Slightly Retro:" The Rehnquist Court's Rout of Habeas Corpus Jurisdiction in Teague v. Lane, 18 NYU Rev I \& Soc Change 537, 541 (1990-91); Gilbert S. Merritt, Access to Federal Courts in Habeas Corpus Cases, 58 Tenn L Rev 145 (1990); Joseph L. Hoffmann, Retroactivity and the Great Writ: How Congress Should Respond to Teague v. Lane, 1990 BYU L Rev 183, 210-15; Note, Resolving Retroactivity After Teague v. Lane, 65 Ind L J 651, 664 (1990); Robert Weisberg, A Great Writ While It Lasted, 81 J Crim L \& Criminol 9, 18-19, 24-25 (1990); Joseph L. Hoffmann, The Supreme Court's New Vision of Federal Habeas Corpus for State Prisoners, 1989 S Ct Rev 165, 19093. 
their sights on the broader jurisprudential implications of Teague's "new rule" doctrine.

This Article seeks to expose the dangers the "new rule" doctrine poses to the legitimacy of the traditional adjudicative process. These dangers are quite serious. If all court decisions are new and surprising, then what right does any court ever have to apply this new and surprising law to a preexisting controversy? Is all adjudication unfairly retroactive? Is all reliance on precedent a sham?

These questions are not merely hypothetical. Teague's conception of precedent cannot be contained within the boundaries of habeas corpus retroactivity doctrine. It has already begun to leak. State and lower federal courts interpret the statements in Teague cases-that a rule is new because it is not "dictated by precedent"- to be statements not just about the retroactivity of the rule, but also about the rightness of the rule. ${ }^{8}$ Even the Court itself recently used the discussion of precedent in a Teague case to support a ruling on the merits. ${ }^{9}$ This confusion is inevitable because the Teague way of reading precedent (as narrowly as possible) directly conflicts with the way cases are usually read (for their principles and analogies, not just their facts).

In short, this Article explains how Teague threatens conventional jurisprudence. Section I traces Teague's doctrinal pedigree and shows its incoherence. Section II digs deeper, showing that the incoherence of Teague results from the incompatibility of the positive law concept of "newness" and the common law concept of "holding" that Teague tries to unite. Section III rethinks what reliance on precedent could mean and determines when reliance might be considered reasonable. Section IV offers pragmatic suggestions about how the Court might proceed.

7 See, for example, Fallon and Meltzer, 104 Harv L Rev at 1758-77 (addressing the jurisprudential debate between positive law and common law theories of precedent, but finding it unhelpful as an approach to retroactivity questions); Hoffmann, 1990 BYU L Rev at $189 \mathrm{n} 22$ (" $[\mathrm{E}]$ fforts to solve the retroactivity problem in habeas corpus by resorting to jurisprudential inquiry have proven futile.").

See Dubber, $30 \mathrm{Am}$ Crim L Rev at 32 (cited in note 1).

9 See Johnson $v$ Texas, $113 \mathrm{~S} \mathrm{Ct} 2658,2668$ (1993) (discussed in text accompanying notes $166-68)$. 


\section{BACKGROUND}

\section{A. The Origins of Non-Retroactivity}

Teague's rule of non-retroactivity was itself a new rule. Before 1965, the Supreme Court assumed all of its decisions should apply retroactively. ${ }^{10}$ Retroactivity first became an issue when the Supreme Court began interpreting the Due Process Clause of the Fourteenth Amendment to require state courts to provide criminal defendants the same Fourth, Fifth, and Sixth Amendment protections that the federal courts were obligated to provide. Only then, after overruling decades of precedent holding state governments to more lenient standards than the federal government, and faced with the prospect of overturning convictions decades old, did the Supreme Court first raise the question whether its rulings should be retroactive. It had never squarely faced this question before,${ }^{11}$ primarily because the changes in its criminal law doctrines had been incremental and evolutionary, not revolutionary.

The retroactivity question was not only practically problematic but also conceptually confounding because it required the Court to consider the very nature of judging. Traditionally, a judge is hemmed in by two principles. On the one hand, she must judge within a context, after a dispute has arisen-she must not render "advisory opinions." On the other hand, she must not hold parties to standards they could not have anticipated. In other words, judges can neither rule "purely prospectively," announcing rules only for the future, nor rule retroactively, applying new rules to disputes that arose in the past. The traditional middle course between these principles, attributed to William Blackstone, was that judges are "not delegated to pronounce a

${ }^{10}$ See Linkletter $v$ Walker, 381 US 618, 628 n 13 (1965) (citing cases).

11 The closest the Court had come was to sustain prospective state judicial decisions against due process attacks. See Great Northern Railway Co. v Sunburst Oil \& Refining Co., 287 US 358, 363-67 (1932). But federal constitutional decisions had always been retroactive. See Norton v Shelby County, 118 US 425, 442 (1886); Linkletter, 381 US at 628. In James $v$ United States, 366 US 213 (1961), the Court overruled prior law so as to criminalize the willful failure to report embezzled funds as gross income, but the Court refused to uphold the defendant's conviction for such failure. However, James never mentioned prospectivity. Instead, the Court's reversal of the embezzlement conviction turned on the defendant's lack of willfulness, since he did not and could not have known his conduct would violate the tax laws. Id at 221-22. But see Note, Prospective Overruling and Retroactive Application in the Federal Courts, 71 Yale L J 907, 921 (1962) (noting that despite jealous judicial adherence to the doctrine of retroactivity, courts had applied the practice of prospective overruling in some circumstances; thus prospectivity was "not novel" when the Court first passed upon its constitutionality in Sunburst). 
new law, but to maintain and expound the old one."12 They then apply these preexisting laws to resolve the disputes before them. That is, they apply old rules to resolve old cases. ${ }^{13}$ But could the Court therefore say that, in applying the Bill of Rights to the states for the first time, it was merely applying preexisting law?

No. The Court declined to invoke what contemporary commentators dismissed as the "prim lore"14 that it had hitherto

${ }^{12}$ But even in such cases [where previous decisions are overruled] the subsequent judges do not pretend to make a new law, but to vindicate the old one from misrepresentation. For if it be found that the former decision is manifestly absurd or unjust, it is declared, not that such a sentence was bad law; but that it was not law ....

...

... Upon the whole, however we may take it as a general rule, "that the decisions of courts of justice are the evidence of what is common law ...."

William M. Blackstone, 1 Commentaries *69-70.

This idea is actually much older than Blackstone-arising perhaps even "from time immemorial." See J.G.A. Pocock, The Ancient Constitution and the Feudal Law: A Study of English Historical Thought in the Seventeenth Century: A Reissue With a Retrospect 30-41 (Cambridge, 1987). "The belief in the ancient [unwritten] constitution therefore rested on assumptions which were fundamental to the practice of the common law, and it had very great influence in a society whose political and social thinking were so largely dominated by this one law. It cannot therefore be regarded as the creation of any single mind." Id at 38. However, the idea "received its classic formulation soon after 1600 from Sir Edward Coke ...." Id at 31. See also Sir Matthew Hale, The History of the Common Law of England 45 (Chicago, 1971) ('Decisions of Courts of Justice, tho' by Virtue of the Laws of this Realm they do bind ... do not make a Law properly so called (for that only the King and Parliament can do); yet they have a great Weight and Authority in Expounding, Declaring, and Publishing what the Law of this Kingdom is ....").

is [I]n terms of fairness, a court, to a much greater degree than a legislature, acts by applying rules in a retroactive manner. This in turn gives rise to what might be called the retroactivity dilemma: how can it be fair to resolve a dispute concerning a past transaction by applying a legal rule that is articulated after the transaction occurred? Requiring courts to reason from existing standards alleviates (although it does not eliminate) this dilemma, by ensuring that decisions are rooted in standards that the disputants either knew or had reason to know at the time of their transaction, albeit standards that had perhaps not previously been officially recognized as legal rules.

Melvin Aron Eisenberg, The Nature of the Common Law 10 (Harvard, 1988).

The key distinction between courts and legislatures has often been thought to be that legislatures make new law prospectively, and courts apply old law retroactively. In the 1993 Term, the Court will decide two cases concerning the retroactivity of the Civil Rights Act of 1991. Rivers $v$ Roadway Express, 973 F2d 490 (6th Cir 1992), cert granted, 113 S Ct 1250 (1993); Landgraf v USI Film, Products, 968 F2d 427 (5th Cir 1992), cert granted, $113 \mathrm{~S} \mathrm{Ct} 1250$ (1993). Both cases present the question whether legislation should be presumed to apply only prospectively - whether legislatures are thought only to change the law-or whether legislation may be presumed to apply retroactively when it is intended to overturn a judicial gloss on a statute.

Administrative agencies, which have both adjudicative and rulemaking powers, are even harder to classify: is it appropriate for them to use their adjudicative powers to establish "new" rules of general application, or must they follow rulemaking notice and comment procedures? The answer is not entirely clear. See Kenneth Culp Davis, 2 Administrative Law Treatise § 7:25 at 118-28 (K.C. Davis, 1979) and cases cited therein.

${ }_{14}$ See Roger J. Traynor, Quo Vadis, Prospective Overruling: A Question of Judicial 
simply been wrong about what law was out there. Instead, in Linkletter $v$ Walker, the Court decided that judges do make law. ${ }^{15}$ Linkletter presented the question whether the exclusionary rule of Mapp $v$ Ohio $^{16}$ should be applied to state cases coming to federal court on habeas corpus. In declining to apply Mapp retroactively, the Court explicitly repudiated the Blackstonian view of adjudication that courts declare preexisting law and, instead, favored the positive law approach advocated by John Austin: ${ }^{17}$

Austin maintained that judges do in fact do something more than discover law; they make it interstitially by filling in with judicial interpretation the vague, indefinite, or generic statutory or common-law terms that alone are but the empty crevices of the law. Implicit in such an approach is the admission when a case is overruled that the earlier decision was wrongly decided. However, rather than being erased by the later overruling decision it is considered as an existing juridical fact until overruled, and intermediate cases finally decided under it are not to be disturbed. ${ }^{18}$

Although the Linkletter Court did not realize it, choosing Austin over Blackstone would have repercussions for the Court's view of precedent. If judges make law, then the precise words they use are themselves authoritative-"an existing juridical fact until overruled." If judges merely find law, then their words are helpful and illustrative, but not in themselves binding. So, in a common law framework, the force of a precedent lies in its reasoning, however imprecisely expressed; in a positive law framework, the force of a precedent lies in the judge's words.

The Linkletter Court, having determined that it should not be shy about making law, concluded that it was "neither required to apply, nor prohibited from applying, a decision retrospectively." The Court proceeded to adopt a pragmatic balancing test for determining whether a decision should be retroactive. ${ }^{20}$ The

Responsibility, 28 Hastings L J 533, 535 (1977).

${ }^{15} 381$ US 618, 628 (1965).

${ }^{16} 367$ US 643 (1961). Mapp overruled Wolf $v$ Colorado, 338 US 25 (1949), to the extent Wolf had declined to apply the exclusionary rule to search and seizure violations by state officials.

17 John Austin is generally credited with the first explication of positive law. See Stanley L. Paulson, Jus Non Scriptum and the Reliance Principle, 75 Mich L Rev 68, 69 (1976) (John Austin's work remains "the locus classicus of legal positivism.").

${ }_{18}$ Linkletter, 381 US at 623-24.

19 Id at 629.

20 "[T]here seems to be no impediment-constitutional or philosophical-to the use of 
test, later formalized in Johnson $v$ New Jersey ${ }^{21}$ and Stovall $v$ Denno, ${ }^{22}$ weighed: "(a) the purpose to be served by the new standards, (b) the extent of the reliance by law enforcement authorities on the old standards, and (c) the effect on the administration of justice of a retroactive application of the new standards."23

As the Court continued to expand constitutional protections for criminal defendants, it applied Linkletter's analysis not only to cases on habeas, but also to cases on direct review, both state and federal. ${ }^{24}$ The analysis also spilled over into non-criminal cases in Cheuron Oil Co. $v$ Huson. ${ }^{25}$ The law reviews of the era heralded these new developments as the culmination of Realism and the overdue spring cleaning of the dusty superstitions of natural law. ${ }^{26}$ Practical policy considerations, not metaphysics,

the [balancing] rule in the constitutional area where the exigencies of the situation require such an application." Id at 628.

21384 US 719 (1966).

22388 US 293 (1967).

${ }^{23}$ Id at 297. See also Johnson $v$ New Jersey, 384 US at 727. Interestingly, this switch from a natural law to a positive law conception of judicial decision making has its lexographical counterpart as well. Around this same time, the official reporter began regularly including the dates of decisions in its citation form, signaling that the date of a decision is suddenly of relevance. The practice is not uniform; some of the opinions by the older Justices do not follow suit.

24 Johnson $v$ New Jersey, 384 US at 726-33 (refusing to apply Miranda $v$ Arizona, 384 US 436 (1966), or Escobedo v Illinois, 378 US 478 (1964), to trials beginning on or before the date of those decisions); Fuller $v$ Alaska, 393 US 80, 81 (1968) (limiting application of a new exclusionary rule established in Lee $v$ Florida, 392 US 378 (1968), to evidence sought to be introduced after Lee was decided); Desist $v$ United States, 394 US 244, 248-54 (1969) (refusing to apply Katz v United States, 389 US 347 (1967), to cases in which the prosecution seeks to introduce electronic surveillance evidence garnered on or before the date of the Katz decision); Jenkins $v$ Delaware, 395 US 213, 217-22 (1969) (refusing to apply Miranda to retrials beginning after Miranda if the original trial had commenced before Miranda).

The Court was by no means consistent about specifying when a decision would be applicable. For example, in Desist, the Court held that the reliance of federal investigators on an old rule required that the new rule only apply to subsequent investigations, while in Johnson $v$ New Jersey, the Court held that Miranda would apply to all subsequent trials, even if the investigation occurred prior to Miranda. See Solem v Stumes, 465 US 638, 650-51 (1984) (citing cases).

${ }_{25} 404$ US 97, 105-09 (1971) (holding that Rodrigue v Aetna Casualty \& Surety Co., 395 US 352 (1969), which would have time-barred respondent's action, would not apply retroactively).

${ }^{26}$ See, for example, Beryl Harold Levy, Realist Jurisprudence and Prospective Overruling, $109 \mathrm{U}$ Pa L Rev 1, 1-2, 25-30 (1960); Traynor, 28 Hastings L J at 534-36 (cited in note 14). See also Lord Reid, The Judge As Law Maker, 12 J Soc'y Pub Teachers L 22 (1972) ("There was a time when it was thought almost indecent to suggest that judges make law-they only declare it. Those with a taste for fairy tales seem to have thought that in some Aladdin's cave there is hidden the Common Law in all its splendor and that on a judge's appointment there descends on him knowledge of the magic words Open Sesame .... But we do not believe in fairy tales anymore."). 
would now determine whether or not a judicial decision should be applied to preexisting disputes or not. Yet, because the Court's approach emphasized pragmatic considerations rather than the extent to which a rule was or was not a break from precedent, the Court did not confront the implication of its new positivism for the reading and interpreting of prior cases. That complication was left for Teague.

The wrinkle in Linkletter's approach that eventually led to its demise was its application of "new rules" to the first litigant, but not to other similarly situated litigants asking for direct review of their decisions. For example, some 80 cases presented the issue decided in Miranda; the Court "took four of them and held the rest and then disposed of each of the four, applying the new procedural rule retroactively. But as respects the rest of the pending cases [the Court] denied any relief .... Y Yet it was sheer coincidence that those precise four were chosen."27 The Court acknowledged the inequity of such "selective prospectivity" in Stovall, but laid it at the door of Article III of the Constitution. ${ }^{28}$

27 Desist, 394 US at 255 (Douglas dissenting). Justice Douglas dissented on this point for over a decade. See Linkletter, 381 US at 641 (Black, with Douglas, dissenting) ("This different treatment of Miss Mapp and Linkletter points up at once the arbitrary and discriminatory nature of the judicial contrivance utilized here ...."); Whisman $v$ Georgia, 384 US 895 (1966) ("Mr. Justice Douglas is of the opinion that certiorari should be granted and the judgment reversed. He would remand the case for a new trial, it being clear from the record that the principles announced in Miranda $v$. Arizona ... were not applied. He sees no reason for discriminating against this petitioner, the case having come here on direct review and being of the same vintage as Miranda v. Arizona."); Fuller, 393 US at 82 ("Mr. Justice Douglas, believing that the rule of Lee v. Florida, 392 U.S. 378, which was applied retroactively in that case, should be applied retroactively in other cases, too, dissents."); Mackey $v$ United States, 401 US 667, 714 (1971) (Douglas dissenting) ("I]t is not comprehensible, if justice rather than the fortuitous circumstances of the time of the trial is the standard, why all victims of the old unconstitutional rule should not be treated equally."); Daniel $v$ Louisiana, 420 US 31, 34 (1975) (Douglas dissenting) ("It is, I think, highly unfair to make the opinion in the case we take retroactive in that appellant's case but not retroactive in others of the same vintage and pending here."); United States $v$ Peltier, 422 US 531, 543 (1975) (Douglas dissenting) ("It is largely a matter of chance that we held the Border Patrol to the command of the Fourth Amendment in Almeida-Sanchez [413 US 266 (1973)] rather than in the case of this defendant. Equal justice does not permit a defendant's fate to depend upon such a fortuity.").

${ }^{23}$ See 388 US at 301:

Sound policies of decision-making, rooted in the command of Article III of the Constitution that we resolve issues solely in concrete cases or controversies, and in the possible effect upon the incentive of counsel to advance contentions requiring a change in the law, militate against denying Wade and Gilbert the benefit of today's decisions. Inequity arguably results from according the benefit of a new rule to the parties in the case in which it is announced but not to other litigants similarly situated in the trial or appellate process who have raised the same issue. But we regard the fact that the parties involved are chance beneficiaries as an insignificant cost for adherence to sound principles of decision-making. 
Justice Harlan, who had joined the majority in Linkletter "to limit the impact of constitutional decisions which seemed to [him] profoundly unsound," ${ }^{29}$ ultimately rejected its selective application of law in his influential separate opinions in Desist ${ }^{30}$ and Mackey. ${ }^{31}$ He suggested that new constitutional decisions be applied to all cases on direct review. "Matters of basic principle are at stake," he wrote. ${ }^{32}$ "In the classical view of constitutional adjudication, which I share, criminal defendants cannot come before this Court simply to request largesse .... We do not release a criminal from jail because we like to do so, or because we think it wise to do so, but only because the government has offended constitutional principle in the conduct of his case. And when another similarly situated defendant comes before us, we must grant the same relief or give a. principled reason for acting differently." According to Justice Harlan, if a new constitutional doctrine was "truly right," the Court had the obligation to apply it "to do justice to each litigant on the merits of his own case. ${ }^{34}$ Otherwise, after the Court announced and applied a new rule, it would be in the anomalous position of reversing appellate court decisions pending on direct review that enunciated the same new rule, even though the Court agreed these decisions were correct on the merits. Lower courts would become leery of developing new doctrine and would be reduced "to the role of automatons, directed by [the Court] to apply mechanistically all then-settled federal constitutional concepts to every case before them."35 Justice Fortas put a point on it: "The vitality of our Constitution depends upon conceptual faithfulness and not merely decisional obedience.".36

Justice Harlan's view of precedent fits firmly within the traditional conception of constitutional adjudication. In this Blackstonian tradition, because the authority of law lies outside the judge's words, opinions can be right or wrong-they are measured against the reason and general principles that emanate from all past decisions, bound together as a coherent whole. If

\footnotetext{
Desist, 394 US at 258 (Harlan dissenting).

Id at 256-69.

401 US at 675-702 (Harlan concurring in part and dissenting in part).

Desist, 394 US at 258 (Harlan dissenting).

Id.

Id at 259.

Mackey, 401 US at 680 (Harlan concurring in part and dissenting in part).

Desist, 394 US at 277 (Fortas dissenting).
} 
Harlan had taken a positive law standpoint, on the other hand, he would have had to say that opinions cannot be right or wrong-a change in law is effected merely by the judge's word. There is no other standard to which to appeal. The question for positive law, then, is not what the right law is, but which statement was valid and authoritative at the time the dispute arose.

Yet Justice Harlan thought different considerations should apply in state cases coming before the Court on habeas corpus. In Mackey, relying on a controversial account of the history of habeas, Justice Harlan asserted that federal courts had historically given more deference to state court decisions on habeas than on direct review. ${ }^{37} \mathrm{He}$ argued that this tradition should continue, out of respect for state court adjudications and out of reluctance to require retrials in long-stale cases. ${ }^{38}$ Consequently, "new" rules should not be applied to habeas petitioners unless they place certain kinds of conduct "beyond the power of the criminal law-making authority to proscribe," or if they adopt new procedures "implicit in the concept of ordered liberty." 39 In distinguishing old from new rules, it is not clear that Harlan himself thought of "new" as newly judge-made in the positive-law sense, but his thoughts certainly led in that direction.

After another decade of unsatisfactory Linkletter opinions, the Court finally implemented, in modified form, Justice Harlan's thoughtful comments. ${ }^{40}$ In Griffith $v$ Kentucky; the Court held that all of its decisions would apply to all cases on direct review. ${ }^{41}$ The Court forswore Linkletter, echoing the arguments

${ }^{37} 401$ US at 682-83. See also Paul M. Bator, Finality in Criminal Law and Federal Habeas Corpus for State Prisoners, 76 Harv L Rev 441, 523-28 (1963). For competing accounts of the habeas chronology, see Fay $v$ Noia, 372 US 391, 402-14 (1963) (per Brennan); Gary Peller, In Defense of Federal Habeas Corpus Relitigation, 16 Harv CR-CL L Rev 579, 610-63 (1982); Woolhandler, 45 Stan L Rev at 587-629 (cited in note 6); James S. Liebman, Apocalypse Next Time?: The Anachronistic Attack on Habeas Corpus/Direct Review Parity, 92 Colum L Rev 1997, 2041-94 (1992).

38 Mackey, 401 US at 690-92 (Harlan concurring in part and dissenting in part).

39 Id at 692-93.

40 An earlier attempt to compromise between Linkletter and Harlan's approach won a majority in United States $v$ Johnson, 457 US 537, 562 (1982), and Shea $v$ Louisiana, 470 US 51, 59 (1985). Under these cases, a new rule would apply retroactively to convictions on direct appeal as long as the rule was not a sharp break from prior precedent. The Court tried to avoid the Linkletter balancing test, both by explicitly treating newness as a threshold question and by raising the newness threshold in direct appeal cases. See also Friedman, 45 Vand L Rev at 811-13 (cited in note 6) (noting that Teague went farther than Harlan had suggested in modifying review of habeas claims).

11479 US 314, 328 (1987) (applying Batson v Kentucky, 476 US 79 (1986), to all cases pending on direct review). The Griffith Court extended United States $v$ Johnson, declaring that a new rule would apply retroactively to cases on direct appeal, even if the new rule 
made by Justices Black, Douglas, and Harlan twenty years before. ${ }^{42}$

Two years later, the Court adopted the other half of Harlan's approach. In Teague, a plurality of the Court announced that new rules of federal constitutional law would not be applied to habeas petitioners. ${ }^{43}$ More importantly, the "newness" of a rule would be a threshold question, so that the Court would not be in the Article III-suspect position of issuing a substantive constitutional opinion and then not applying it to the case in which it was announced. ${ }^{44}$

As a result, the distinction between new and old rules took on a significance in Teague that it had never had under Linkletter. After Teague, a state's reliance on an old rule is as-

constituted a "clear break" with past precedent. 479 US at 326-28.

${ }^{42}$ See Griffith, 479 US at 322-23:

Unlike a legislature, we do not promulgate new rules of constitutional procedure on a broad basis. Rather, the nature of judicial review requires that we adjudicate specific cases, and each case usually becomes the vehicle for announcement of a new rule. But after we have decided a new rule in the case selected, the integrity of judicial review requires that we apply the rule to all similar cases pending on direct review.

...

Second, selective application of new rules violates the principle of treating similarly situated defendants the same.

The Court reached a similar conclusion with respect to civil cases in the line of cases following Chevron Oil Co. $v$ Huson, 404 US 97 (1971), Linkletter's civil twin. The transition happened more slowly, however. The Court had initially distinguished the civil retroactivity cases, which generally involved invalidation of state tax laws with consequent concerns as to the retroactivity of refunds, from cases involving criminal convictions. In American Trucking Ass'ns Inc. v Smith, 496 US 167, 197-99 (1990), a plurality of the Court held that the equitable Linkletter/Cheuron type analysis would govern the retrospective application of new law invalidating tax schemes, despite the per se rule of retroactivity adopted for direct appeal of criminal cases in Griffith. The plurality reasoned that, unlike criminal appellants, civil appellants would not be chilled from appealing their cases by the prospect of non-retroactivity because they also stood to gain from prospective invalidation of the tax. Id at 198-99. Also, the benefit of prospectivity may benefit either party in a civil tax case; in a criminal case, prospectivity skews the benefit toward the government. Id.

However, in the two most recent cases, James B. Beam Distilling Co. $v$ Georgia, 111 S Ct 2439, 2446-48 (1991), and Harper $v$ Virginia Dep't of Taxation, $113 \mathrm{~S}$ Ct 2510, 251718 (1993), the Court abandoned American Trucking, holding that it would not grant one set of plaintiffs relief in a tax case without making the decision retroactive to all others on direct appeal. Although a majority of the Court left open the possibility of a purely prospective enunciation of new law, Justices Scalia and Blackmun took the position that prospective lawmaking is never constitutional, relying on both Article III and Blackstone himself. Beam, $111 \mathrm{~S}$ Ct at 2449-50 (Blackmun concurring); id at 2450-51 (Scalia concurring); Harper, $113 \mathrm{~S}$ Ct at 2520-24 (Scalia concurring).

$489 \mathrm{US}$ at 316.

44 Id at 300 ("Retroactivity is properly treated as a threshold question, for, once a new rule is applied to the defendant in the case announcing the rule, evenhanded justice requires that it be applied to all who are similarly situated."). 
sumed, not proved, and the federal judiciary is prevented from even announcing new rules on habeas. ${ }^{45}$ The courts first decide whether or not habeas petitioners are asking for application of a new rule. If the court decides that a ruling on the merits would require it to announce a new rule, it does not reach the merits at all. The petitioner gets neither a new rule, nor any relief.

This is not to say that the "newness" of a rule had not received any judicial definition under Linkletter. ${ }^{46}$ But during the

${ }^{45}$ See Althouse, $1991 \mathrm{Wis} L$ Rev at $945-50$ (cited in note 6) (pointing out that Teague eliminates concern with practical effects of retroactivity as well as eliminating the lower federal courts' role in developing constitutional law in areas of state criminal procedure); Patchel, 42 Hastings $\mathrm{L} \mathrm{J}$ at 1012-28 (cited in note 6) (noting Teague eliminates the dialogic relation between state and federal courts in developing and elaborating constitutional criminal process requirements). For a description of this dialogic relation, see Robert T. Cover and T. Alexander Aleinikoff, Dialectical Federalism: Habeas Corpus and the Court, 86 Yale L J 1035 (1977).

46 The Linkletter line of decisions considered to be "new" a series of cases increasingly similar to their precedents. Linkletter and other early cases addressed retroactivity only when a prior Supreme Court case had actually been overruled. Consider Linkletter, 381 US 618 (addressing the retroactivity of Mapp v Ohio, 367 US 643 (1961), which partially overruled Wolf $v$ Colorado, 338 US 25 (1949)); Tehan $v$ Shott, 382 US 406 (1966) (addressing the retroactivity of Griffin $v$ California, 380 US 609 (1965), which effectively overruled Twining $v$ New Jersey, 211 US 78 (1908)); DeStefano $v$ Woods, 392 US 631 (1968) (addressing the retroactivity of Duncan v Louisiana, 391 US 145 (1968), and Bloom v Illinois, 391 US 194 (1968), which overruled Maxwell v Dow, 176 US 581 (1900)); Fuller v Alaska, 393 US 80 (1968) (addressing the retroactivity of Lee $v$ Florida, 392 US 378 (1968), which overruled Schwartz v Texas, 344 US 199 (1952)); Desist $v$ United States, 394 US 244 (1969) (addressing the retroactivity of Katz v United States, 389 US 347 (1967), which overruled Olmstead v United States, 277 US 438 (1928), and Goldman v United States, 316 US 129 (1942)); Williams v United States, 401 US 646 (1971) (addressing the retroactivity of Chimel $v$ California, 395 US 752 (1969), which overruled United States $v$ Rabinowitz, 339 US 56 (1950), and Harris v United States, 331 US 145 (1947)); Daniel v Louisiana, 420 US 31 (1975) (addressing the retroactivity of Taylor $v$ Louisiana, 419 US 522 (1975), which overruled Hoyt $v$ Florida, 368 US 57 (1961)); Allen $v$ Hardy, 478 US 255 (1986) (addressing the retroactivity of Batson $v$ Kentucky, 476 US 79 (1986), which overruled in part Swain v Alabama, 380 US 202 (1965)).

In Gosa $v$ Mayden, 413 US 665, 672-73 (1973), however, the Court held that a "clear break with the past" was a new rule, even if it "did not expressly overrule any prior decision, [because] it did announce a new constitutional principle, and it effected a decisional change in attitude that had prevailed for many decades." Further, in Stovall v Denno, 388 US 293, 299-300 (1967), the Court held that a case of first impression established a new rule: "Today's rulings were not foreshadowed in our cases; no court announced such a requirement until Wade was decided by the [Fifth Circuit]. The overwhelming majority of American courts have always treated the evidence question not as one of admissibility but as one of credibility for the jury." Finally, United States $v$ Peltier, 422 US 531, 534 (1975), established an even lower threshold of newness, holding that Almeida-Sanchez $v$ United States, 413 US 266 (1973), a case "overrul[ing] a consistent line of Court of Appeals precedent and disrupt[ing] a long accepted and widely relied upon administrative practice," created a new rule.

The trend was by no means steady, however, as illustrated by the inconsistency between Roberts $v$ Russell, 392 US 293 (1968), and Desist. In Roberts, the Court held that Bruton v United States, 391 US 123 (1968), should be applied retroactively. 392 US at 
Linkletter years, the Court never completely agreed on which cases were new enough to raise doubts about whether or not they should be applied retroactively. In fact, in many cases the Court never said why it was discussing retroactivity. It just did it, treating "newness" as only one factor in the analysis rather than as a prerequisite for applying Linkletter. ${ }^{47}$ More often than not, newness was discussed only as part of the balancing process, in the context of evaluating the reasonableness of the lower courts' reliance on prior law. Hence, Linkletter cases tended to focus judicial attention on the purpose of the rule to be analyzed, rather than on its newness. ${ }^{48}$ As a result, the decisions seemed to turn not so much on the difficult theoretical question of when a law could be said to come into existence, but rather on what good it would do to apply the rule to past cases.

Teague changed that focus to make newness the sole criterion of non-retroactivity in nearly all habeas cases. ${ }^{49}$ Teague an-

293. It reasoned that state officials' reliance upon the pre-Bruton rule was not reasonable, because that rule "ha[d] been under attack from its inception and many courts ha[d] in fact rejected it." Id at 295. See also Berger $v$ California, 393 US 314, 315 (1969) (Barber $v$ Page, 390 US 719 (1968), was "clearly foreshadowed if not preordained" by Pointer $v$ Texas, 380 US 400 (1965), and thus not a new rule); Lee $v$ Missouri, 439 US 461, 462 (1979) (Duren $v$ Missouri, 439 US 357 (1979), was foreshadowed by Taylor $v$ Louisiana, 419 US 522 (1975)); Brown v Louisiana, 447 US 323, 335-36 (1980) (ruling foreshadowed, though a matter of first impression); Yates $v$ Aiken, 484 US 211, 216-17 (1988) (Francis $v$ Franklin, 471 US 307 (1985), was just an application of Sandstrom v Montana, 442 US 510 (1979), and so was not a new rule).

In Desist, the Court held that Katz v United States, 389 US 347 (1967), should not be retroactive. In contrast with the reasoning in Roberts, the Desist court rejected the argument that Katz's overruling of prior precedent had been predictable:

While decisions before Katz may have reflected growing dissatisfaction with the traditional tests of the constitutional validity of electronic surveillance, the Court consistently reiterated those tests and declined invitations to abandon them. However clearly our holding in Katz may have been foreshadowed, it was a clear break with the past, and we are thus compelled to decide whether its application should be limited to the future.

394 US at 248. Although Roberts addressed the newness question under the rubric of reasonable reliance, while Desist considered it as a threshold question, the reasoning of the two cases is irreconcilable. Desist treated the prior precedents as positive law, standing there until explicitly overruled, even if their reason had evaporated. Roberts treated precedent as a body of reasoning, and held lower courts accountable for thoughtful, not unquestioning, obedience.

${ }^{47}$ See, for example, Johnson v New Jersey, 384 US at 726-34; Stovall, 388 US at 296301; Halliday v United States, 394 US 831, 832-33 (1969); DeStefano, 392 US at 633-35; Williams, 401 US at 651-54; Adams $v$ Illinois, 405 US 278, 279-81 (1972); Ivan V. $v$ City of New York, 407 US 203, 204-05 (1972); Michigan v Payne, 412 US 47, $50-57$ (1973).

${ }^{48}$ See Desist, 394 US at 249 (noting the "foremost" consideration in retroactivity analysis is the purpose of the rule sought to be applied); Brown, 447 US at 328.

${ }_{49}$ Teague did leave room for exceptions allowing new rules to be retroactive if they place "certain kinds of primary, private individual conduct beyond the power of the crimi- 
nounced the rule for new rules: "[A] case announces a new rule when it breaks new ground or imposes a new obligation on the States or the Federal Government.... To put it differently, a case announces a new rule if the result was not dictated by precedent existing at the time the defendant's conviction became final." ${ }^{\text {"No }}$ The Court, having begun to take the positivist plunge in Linkletter, completed it in Teague by making the Court's lawmaking its sole inquiry. The jurisprudential problems, not the prudential ones, came to the fore.

Teague itself seemed to adopt a positive-law approach to precedent; it looked to see whether the words themselves in prior cases did indeed establish a rule, or whether the petitioner was asking for a new rule. Mr. Teague, a black man who had been convicted by an all-white jury, argued that the Sixth Amendment entitled him to a petit jury representing a fair cross-section of his community. He reasoned that the principles of Taylor $v$ Louisi$a n a,{ }^{51}$ which required the jury venire to be drawn from a fair cross-section of the community, should apply to the actual composition of the petit jury as well. ${ }^{52}$ The plurality opinion disagreed, pointing out that Taylor had expressly limited its holding by stating that "[d]efendants are not entitled to a jury of a particular composition." ${ }^{33}$ According to the Teague plurality, then, a position contrary to language in a prior case, even if not contrary to its underlying reason, would constitute a new rule. ${ }^{54}$ This holding is certainly positivist in spirit, since it locates the force of a prior opinion in the language of the judge-lawmaker, not in the reason or sense of the case.

nal law-making authority to proscribe," 489 US at 311, quoting Mackey, 401 US at 692 (Harlan concurring in part and dissenting in part), or if they are "watershed rules of criminal procedure," 489 US at 311, "without which the likelihood of an accurate conviction is seriously diminished." Id at 313. Teague predicted that it was "unlikely that many such components of basic due process have yet to emerge. Id. Indeed, none have so far.

Teague's narrow exceptions to the rule of non-retroactivity have led many commentators to advocate widening them or adding to the list. See, for example, Note, 57 Brooklyn L Rev at 894-902 (cited in note 6); Goldstein, 18 NYU Rev L \& Soc Change at 387-95 (cited in note 6); Note, 65 Ind L J at 671-72 (cited in note 6); Hoffmann, 1990 BYU L Rev at 210-15 (cited in note 6).

so Teague, 489 US at 301.

51419 US 522 (1975).

52 Teague, 489 US at 299.

53 Taylor, 419 US at 538.

${ }^{54}$ See Teague, 489 US at 301 ("Given the strong language in Taylor and our statement in [Akins $v$ Texas, 325 US 398, 403 (1945)] application of the fair cross-section to the petit jury would be a new rule."). 
The Court has not maintained this positive law version of precedent, however. As the next subsection reveals, in the cases following Teague the Court has not taken the view that the holding (or precedential force) of a case is derived from the actual words used in the opinion. Instead, the Court has allowed state courts to reinterpret the holdings of past cases, distinguishing cases on their facts even when the language of the opinions, taken literally, would govern. In short, the Court has combined its new rule doctrine with a common law, not a positive law, conception of precedent. Consequently, a "new rule" seems to be any case factually distinguishable from a previous case-that is, nearly every case. This approach to doctrinal analysis threatens to reduce the Court's past opinions to irrelevancies because none of them can "dictate" a later result. Teague's approach also calls into question the legitimacy of applying any decision retroactively. Moreover, the number of separate opinions and the shifting positions of the Justices in Teague's progeny illustrate that the Court is aware of the slippery slope it is traversing.

\section{B. The Fruitless Search for the Essence of Newness}

The first post-Teague case did not find a new rule. In Penry $v$ Lynaugh, the Court allowed a habeas petitioner to challenge the sentencing procedure under which he received the death penalty. ${ }^{55} \mathrm{Mr}$. Penry had been convicted of capital murder in Texas. Although evidence at trial showed that he was mentally retarded and had the mental age of a child of six and one-half years, he was nonetheless convicted and sentenced to death. On federal habeas, Penry claimed that the Texas sentencing scheme had unconstitutionally limited the ability of jurors to consider his retardation in mitigation of his offense. In terms of precedent, Penry's case fell between Jurek $v$ Texas, ${ }^{56}$ which had upheld the facial validity of the Texas death penalty statute, and Lockett $v$ Ohio ${ }^{57}$ and Eddings $v$ Oklahoma, ${ }^{58}$ which had struck down death penalty schemes that did not allow consideration of mitigating evidence. ${ }^{59}$ Penry argued that the Texas statute, as ap-

ss 492 US 302 (1989).

${ }^{56} 428$ US 262, $276(1976)$.

57438 US 586, 608-09 (1978).

ss 455 US 104, 110-16 (1982).

59 Lockett involved an Ohio statute that restricted mitigating evidence to the following categories: (1) when the victim induced or facilitated the offense; (2) when defendant was under duress, coercion, or strong provocation; and (3) when the crime resulted from defendant's psychosis or mental deficiency, 438 US at 593-94. The Court invalidated the 
plied to him, did not permit the sentencing jury to give mitigating effect to the evidence of his mental retardation. ${ }^{60}$ Under the statute, his retardation was relevant only with regard to (1) whether he acted "deliberately and with the reasonable expectation" that death would result; (2) whether there was a probability he "would commit criminal acts of violence that would constitute a continuing threat to society"; and (3) whether his conduct "in killing the deceased was unreasonable in response to the provocation, if any, by the deceased." ${ }^{11}$ Penry argued that his evidence of mental retardation had relevance to his moral culpability beyond the scope of these special issues, and thus the Texas statute was invalid under Lockett and Eddings as applied to him.

Split 5-4, the Court reasoned that Penry's claim was an old one, not barred by Teague. ${ }^{2}$ Both Lockett and Eddings predated

statute, and the plurality opinion stated: "[W]e conclude that the Eighth and Fourteenth Amendments require that the sentencer, in all but the rarest kind of capital case, not be precluded from considering, as a mitigating factor, any aspect of the defendant's character or record and any of the circumstances of the offense that the defendant proffers as a basis for a sentence less than death." Id at 604 .

Eddings involved a judge who, at sentencing, had refused to consider evidence of the defendant's "troubled youth." The Court stated: "We find that the limitations placed by these courts upon the mitigating evidence they would consider violated the rule in Lockett. Just as the State may not by statute preclude the sentencer from considering any mitigating factor, neither may the sentencer refuse to consider, as a matter of law, any relevant mitigating evidence." 455 US at 113-14. The Court went on to say that the sentencing judge had also erred in failing to take into account the full weight of the defendant's youth:

The trial judge recognized that youth must be considered a relevant mitigating factor. But youth is more than a chronological fact. It is a time and condition of life when a person may be most susceptible to influence and to psychological damage. Our history is replete with laws and judicial recognition that minors, especially in their earlier years, generally are less mature and responsible than adults. Particularly "during the formative years of childhood and adolescence, minors often lack the experience, perspective and judgment" expected of adults.

Id at 115-16, quoting Belotti v Baird, 443 US 622, 635 (1979).

${ }^{60}$ Penry, 492 US at 312.

61 Id at 310 .

62 The portion of Justice O'Connor's majority opinion that declared Teague applicable to capital sentencing cases was joined by Chief Justice Rehnquist and Justices White, Scalia, and Kennedy. 492 US at 313-14. In separate opinions, Justices Brennan and Marshall reiterated their opposition to Teague, id at 341-49 (Brennan and Marshall concurring in part and dissenting in part), and Justices Stevens and Blackmun expressed their discomfort with deciding newness as a threshold question. Id at 349-50 (Stevens and Blackman concurring in part and dissenting in part).

With respect to whether the ruling Penry sought was a new rule, the Court split in a different 5-4 configuration. The majority decided that it was not a new rule, as Justices Brennan, Marshall, Blackman, and Stevens joined O'Connor's opinion. Id at 314-19. Justice Scalia, joined by Chief Justice Rehnquist, and Justices White and Kennedy, dissented as to the newness issue. Id at 351-53 (Scalia concurring in part and dissenting in part). Scalia argued that, given Jurek's validation of the Texas scheme, Penry's request clearly 
Penry's application for certiorari on direct appeal, and although they did not call into question the constitutionality of the Texas statute as upheld in Jurek, the Texas statute had been upheld only "on the basis of assurances that the special issues would be interpreted broadly enough to enable sentencing juries to consider all of the relevant mitigating evidence a defendant might present."63 Because Penry claimed those assurances had not been met in his case, he was not asking for a new rule, but instead for application of principles already established in Lockett and Eddings. ${ }^{64}$

Penry's relatively forgiving approach to "dictated by precedent" (namely, reading prior cases to establish relatively general principles) did not last. The understanding of "newness" that did prevail unfolded in Butler $v$ McKellar, another 5-4 decision. ${ }^{65}$ Along with subsequent cases, Butler effectively limited Penry to its facts. ${ }^{66}$

Butler sought federal habeas because police had interrogated him about the capital murder he was ultimately convicted of while he was in custody on another charge, and after he had invoked his right to counsel on the other charge. ${ }^{67}$ This police conduct, Butler argued, violated Edwards $v$ Arizona, which held that a suspect who has "expressed his desire to deal with the police only through counsel is not subject to further investigation by the authorities until counsel has been made available to him,

called for a new rule. Id.

63 Id at 318 . See also Lockett, 438 US at 606-07:

Jurek involved a Texas statute which made no explicit reference to mitigating factors .... Rather, the jury was required to answer three questions in the sentencing process, the second of which was "whether there is a probability that the defendant would commit criminal acts of violence that would constitute a continuing threat to society." ... The statute survived the petitioner's Eighth and Fourteenth Amendment attack because three Justices concluded that the Texas Court of Criminal Appeals had broadly interpreted the second question-despite its facial narrowness-so as to permit the sentencer to consider "whatever mitigating circumstances" the defendant might be able to show .... None of the statutes we sustained in Gregg and the companion cases clearly operated at that time to prevent the sentencer from considering any aspect of the defendant's character and record or any circumstances of his offense as an independently mitigating factor.

64 Penry, 492 US at 318-19 ("Penry argues that those assurances were not fulfilled in his particular case because, without appropriate instructions, the jury could not fully consider and give effect to the mitigating evidence of his mental retardation and abused childhood in rendering its sentencing decision. The rule Penry seeks . . . is not a 'new rule' under Teague because it is dictated by Eddings and Lockett.").

65 494 US 407 (1990). Chief Justice Rehnquist wrote the opinion for the Court; Justice Brennan, joined by Justices Marshall, Blackmun, and Stevens, dissented.

66 See, in particular, the text accompanying notes $86-88,117-22$.

67 Butler, 494 US at 408-10. 
unless the accused himself initiates further communication, exchanges, or conversations with the police."68

The Fourth Circuit first refused to extend Edwards to Butler's situation, ${ }^{69}$ but just after that ruling, the Supreme Court decided Arizona $v$ Roberson, which held that Edwards did preclude police from initiating questioning on another charge after an accused already in custody has invoked his right to counsel. ${ }^{70}$ The Fourth Circuit denied Butler's motion for reconsideration on the ground that Roberson established a new rule that should not be retroactive on habeas. ${ }^{71}$

Butler argued that Roberson did not establish a new rule, but merely applied Edwards to a slightly different set of facts. ${ }^{72}$ He relied primarily on language in Roberson itself. The Roberson Court had stated that continued interrogation of a suspect who had requested counsel violated the express rule articulated in $E d w a r d s$, and then ruled that the fact that the police re-initiated questioning to ask about a different crime was a distinction without a difference. ${ }^{73}$

The Butler Court held that Roberson was not "dictated" by Edwards. ${ }^{74}$ Noting that the Teague rule was intended to protect the state courts' reasonable reliance on precedent, the Court injected a new twist into the "newness" test: a rule would be new if its newness were "susceptible to debate among reasonable minds." The Court even stated that Roberson's own character-

68451 US 477, 484-85 (1981).

69 Butler v Aiken, 846 F2d 255 (4th Cir 1988).

70 Arizona v Roberson, 486 US 675, 682 (1988).

71 Butler v Aiken, 864 F2d 24 (4th Cir 1988).

72 Butler, 494 US at 414.

${ }^{73}$ Roberson, 486 US at 677-78. The first paragraph of the opinion reads:

In [Edwards v Arizona, 451 US 477, 484-85 (1981)], we held that a suspect who has "expressed his desire to deal with the police only through counsel is not subject to further interrogation by the authorities until counsel has been made available to him, unless the accused himself initiates further communication, exchanges, or conversations with the police." In this case, Arizona asks us to craft an exception to that rule for cases in which the police want to interrogate a suspect about an offense that is unrelated to the subject of their initial interrogation. Several years ago the Arizona Supreme Court considered, and rejected, a similar argument, stating:

The only difference between Edwards and the appellant is that Edwards was questioned about the same offense after a request for counsel while the appellant was reinterrogated about an unrelated offense. We do not believe that this factual distinction holds any legal significance for fifth amendment purposes.

We agree with the Arizona Supreme Court's conclusion.

Id, citing State $v$ Routhier, 137 Ariz 90, 97, 669 P2d 68, 75 (1983).

74 Butler, 494 US at 409, 415.

75 Id. The Court also analogized Teague's standard to United States $v$ Leon, 468 US 897, 918-19 (1984), which refused to require the exclusion of evidence obtained as a result 
ization of its holding was not dispositive: "[T] says that its decision is within the 'logical compass' of an earlier decision, or indeed that it is 'controlled' by a prior decision, is not conclusive for purposes of deciding whether the current decision is a 'new rule' under Teague. Courts frequently view their decisions as being 'controlled' or 'governed' by prior opinions even when aware of reasonable contrary conclusions reached by other courts." ${ }^{36}$ Finally, the Court considered actual lower court disagreement, regardless of the soundness of the lower court decisions, to be sufficient evidence of reasonable disagreement. ${ }^{77}$

In sum, Butler made clear that: (1) any decision, reasonably distinguishable on its facts from prior decisions, constitutes a new rule; (2) a state court may reasonably distinguish a Supreme Court case, even if the rule as actually enunciated in the case would by its terms apply; and (3) actual disagreement among courts is evidence of reasonable disagreement.

Of course, if this last proposition is taken seriously, the very fact that a state court denied a prisoner's claim provides evidence that the state court was reasonable, and seizing any fact by which to distinguish a precedent would be likewise reasonable. A precedent would only "dictate" a result if its facts were completely identical to those in the case at bar. Therefore, because there is no such thing as two identical cases, Butler's reasoning strips precedent of all its force. ${ }^{78}$ Moreover, the Court has put itself in

of illegal searches that police had honestly and reasonably thought valid. Butler, 494 US at 414. Many commentators have also noted Teague's resemblance to the qualified immunity doctrine. See Fallon and Meltzer, 104 Harv L Rev at 1749-53 (cited in note 6); Hoffmann, 1990 BYU L Rev at $212 \mathrm{n} 126$ (cited in note 6); Woolhandler, 45 Stan L Rev at 635-40 (cited in note 6); Kinports, 33 Ariz L Rev at 115-16 (cited in note 6). However, the consequences for the legitimacy of adjudication are different in contexts where judges speak to other judges or lawyers. As Justice Brennan pointed out in his Butler dissent, police officers and other government officials are to execute the laws, not to interpret them. 494 US at $425 \mathrm{n} 6$ (Brennan dissenting). They perhaps should not be held to understand every nuance of case law; in contrast, "state courts entertaining constitutional challenges to criminal proceedings are expected independently to evaluate these challenges in light of their best understanding of prevailing legal standards embodied in precedent." Id. See also Althouse, 1991 Wis L Rev at 959-60 (cited in note 6) (arguing that the similarity between Teague and qualified immunity is "highly deceptive": "judges have a special duty to interpret the law and delve into its unclarities .... Expecting them to perform this task is far more reasonable and fair than, say, expecting a police officer to ponder subtleties of Fourth Amendment law in the midst of conducting a search."); Patchel, 42 Hastings $I J$ at $998 \mathrm{n} 343$ (cited in note 6). For a more detailed discussion of qualified immunity cases, see the text accompanying notes 234-36.

${ }^{76}$ Butler, 494 US at 415.

77 Id ("That the outcome in Roberson was susceptible to debate among reasonable minds is evidenced further by the differing positions taken by the judges of the Courts of Appeals for the Fourth and Seventh Circuits ....").

78 Compare Althouse, 1991 Wis L Rev at 966 (pointing out that the skepticism about 
the position of disavowing its reasoning in prior cases on the merits; conclusions drawn from precedent are only window dressing, not to be taken seriously.

Justice Brennan filed strong dissents in both Butler and Teague. ${ }^{79} \mathrm{He}$ accurately forecast that the new rule doctrine would culminate in complete habeas court deference to previous adjudications that did not amount to "outright 'illogical' defiance of a binding precedent precisely on point." $\mathrm{He}$ also sensed the effect such a reading would have on the Court's basic understanding of adjudication itself:

The Court's exceedingly broad definition of "new rule"-and conversely its narrow definition of "prevailing" law-betrays a vision of adjudication fundamentally at odds with any this Court has previously recognized. According to Justice Harlan, whose retroactivity jurisprudence undergirds Teague and its progeny: "One need not be a rigid partisan of Blackstone to recognize that many, though not all, of this Court's constitutional decisions are grounded upon fundamental principles whose content does not change dramatically from year to year, but whose meanings are altered slowly and subtly as generation succeeds generation." As every first-year law student learns, adjudication according to pre-

judging apparent in the Butler opinion undermines judicial decision making: "To dispell [sic] the illusion [of the coherence of law] is to undermine the power of judges, to undercut the reverence for the rights they create, and to reveal the needlessness of their antidemocratic role."); Patchel, 42 Hastings L J at 1011 (suggesting that the Butler opinion assumes a "nihilistic view of constitutional adjudication"); Larry W. Yackle, The Habeas Hagioscope, 66 S Cal L Rev 2331, 2389-91 (1993) (same). See also Fallon and Meltzer, 104 Harv L Rev at 1748:

The conception of legal newness implicit in Teague and its progeny is difficult to reconcile with the conception of the judicial role embraced by Justice Harlan. Whereas Justice Harlan viewed the law as a fabric stitched together by reason, the current Court often sounds as if in the thrall of the kind of starkly positivist, judicial lawmaking paradigm that Justice Harlan expressly rejected. In Butler v. McKellar, for example, the Court denominated as new a decision it had previously characterized as "controlled" by a settled precedent. Chief Justice Rehnquist's majority opinion dismissed the prior characterization as a polite formula whose claim to descriptive accuracy had dissolved under the acids of legal realism: courts commonly describe "their decisions as being 'controlled' or 'governed' by prior opinions" even when the outcome is "susceptible to debate among reasonable minds." When debate is possible, Chief Justice Rehnquist reasoned, prior law does not really control; judges must choose. Their choice is controlled by will, and becomes the law only because judges make it so.

${ }_{79}$ See Butler, 494 US at $417-32$ (Brennan dissenting); Teague, 489 US at 326-45 (Brennan dissenting).

80 Butler, 494 US at 424 (Brennan dissenting). 
vailing law means far more than obeying precedent by perfunctorily applying holdings in previous cases to virtually identical fact patterns. Rather, such adjudication requires a judge to evaluate both the content of previously enunciated legal rules and the breadth of their application. A judge must thereby discern whether the principles applied to specific fact patterns in prior cases fairly extend to govern analogous factual patterns .... The inability of lower courts to predict significant reformulations by this Court of the principles underlying prior precedents does not excuse them from the obligation to draw reasoned conclusions from principles that are well established at the time of their decisions. ${ }^{81}$

Justice Brennan also challenged the Court's willingness to rely on contrary rulings by lower courts in determining whether there could be reasonable disagreement as to a rule's newness:

The majority might mean to suggest that a particular result is reasonable so long as a certain number of courts reach the same result. But this would be an odd criterion for "reasonableness." Its application would be ad hoc, both because there appears to be no principled basis for choosing any particular number of courts whose agreement is required before the result is deemed "reasonable," and because the criterion ultimately rests on a bootstrap to the extent that the later courts reaching the result simply rely on the earlier courts' having done the same. ${ }^{82}$

Disregarding Justice Brennan's discerning comments, the Court continued to interpret "dictated by precedent" narrowly. In Saffle $v$ Parks, ${ }^{83}$ decided in the same Term as Butler, the Court solidified Butler's interpretation of Teague. Parks argued that instructing the jury to avoid "any influence of sympathy, sentiment, passion, prejudice, or other arbitrary factor" when determining whether to impose the death penalty violated the Eighth Amendment's prohibition against cruel and unusual punishment. ${ }^{84}$ Parks reasoned that forbidding the jury from taking into account "any sympathy" generated by mitigating evidence was

81 Id at 422-23 (citation omitted).

82 Id at 421.

83494 US 484 (1990). Justice Kennedy delivered the opinion of the Court. Again, Justice Brennan, joined by Justices Marshall, Blackmun, and Stevens, dissented.

st Id at 487 . 
equivalent to barring relevant mitigating evidence altogether, a result expressly forbidden by Lockett and Eddings. ${ }^{85}$

The Court denied Parks relief, holding that he was asking for a new rule. ${ }^{86}$ It distinguished Parks's proposed rule from that in Lockett and Eddings on the ground that the jury was not prevented from giving some effect to the mitigating evidence, but only prevented from giving it a particular effect. ${ }^{87}$ Likewise, the Court distinguished Penry on the ground that, like Lockett and Eddings, it involved the outright exclusion of mitigating evidence rather than a question of its relevance. ${ }^{88}$

In one stroke, the Court managed to limit the scope of Penry, old rules, and Parks's claim. The Court even adopted an interpretation of Penry at odds with the language in Penry itself. ${ }^{89}$ Just as Butler treated Roberson, the Parks Court found that the view

${ }^{85}$ Id at $488-89$.
${ }^{8}$ Id at 489.

${ }^{87}$ Lockett and Eddings do not seek directly, if at all; to address the issue presented here: whether the State may instruct the sentencer to render its decision on the evidence without sympathy. Parks asks us to create a rule relating, not to what mitigating evidence the jury must be permitted to consider in making its sentencing decision but to how it must consider the mitigating evidence. There is a simple and logical difference between rules that govern what factors the jury must be permitted to consider in making its sentencing decision, and rules that govern how the State may guide the jury in considering and weighing those factors in reaching a decision. We thus cannot say that the large majority of federal and state courts that have rejected challenges to antisympathy instructions similar to that given at Parks' trial have been unreasonable in concluding that the instructions do not violate the rule of Lockett and Eddings . . . . Even were we to agree with Parks' assertion that our decisions in Lockett and Eddings inform, or even control or govern, the analysis of his claim, it does not follow that they compel the rule that Parks seeks.

Id at 490-91.

88 Lockett and Eddings command that the State must allow the jury to give effect to mitigating evidence in making the sentencing decision; Penry's contention was that Texas barred the jury from so acting. Here, by contrast, there is no contention that the state altogether prevented Parks' jury from considering, weighing, and giving effect to all of the mitigating evidence that Parks put before them; rather, Parks' contention is that the State has unconstitutionally limited the manner in which his mitigating evidence may be considered. As we have concluded above, the former contention would come under the rule of Lockett and Eddings; the latter does not.

Id at 491.

${ }^{89}$ The Penry Court noted that:

Penry argues that his mitigating evidence of mental retardation and childhood abuse has relevance to his moral culpability beyond the scope of the special issues, and that the jury was unable to express its "reasoned moral response" to that evidence in determining whether death was the appropriate punishment. We agree. Thus, we reject the State's contrary argument that the jury was able to consider and give effect to all of Penry's mitigating evidence in answering the special issues without any jury instructions on mitigating evidence.

492 US at 322 (emphases added). See also the discussion of Graham $v$ Collins at text accompanying notes $117-24$. 
expressed by the Penry Court itself did not settle the question of whether a decision set forth a new rule. In accord with the common law conception of precedent, state courts were entitled to distinguish Supreme Court decisions on their facts.

The next case, Sawyer $v$ Smith, followed suit. ${ }^{90}$ The Court, per Justice Kennedy, considered the newness of the holding in Caldwell $v$ Mississippi that the Eighth Amendment prohibited a prosecutor in a capital case from mischaracterizing appellate review to the jury so as to diminish the jury's sense of responsibility for its decision. ${ }^{91}$ Sawyer argued that Caldwell was the logical outcome of a series of cases requiring states to ensure that capital sentencing juries take their task seriously, consider all relevant evidence, and turn in an especially reliable verdict. ${ }^{92}$ He also argued that any state's reliance on a contrary rule would be unreasonable, given the number of states that had already adopted Caldwell-type rules prior to the decision in Caldwell itself..$^{93}$

Sawyer's rejection of these arguments confirmed that Teague's definition of new rules included "gradual developments in the law over which reasonable jurists may disagree." Sawyer Court required that the "rule" sought by the litigant be characterized at a low level of generality. ${ }^{95}$ The principles established in the earlier cases cited by Sawyer were simply too general to enable state courts to predict the result in Caldwell. ${ }^{96}$ Instead, the proper question was whether the Court had ever before held a prosecutor's misrepresentation of the nature of appellate review to be an Eighth Amendment violation. ${ }^{97}$

The Court's latest cases reflect some uneasiness with the extent to which Teague makes it possible to characterize any case, distinguishable on its facts from prior precedent, as "new." In Stringer $v$ Black, ${ }^{98}$ the Court, again per Justice Kennedy, opined that Maynard $v$ Cartwright ${ }^{99}$ and Clemons $v$ Mis-

90497 US 227 (1990). Again, the decision was 5-4, with Justice Marshall dissenting, joined by Justices Brennan, Blackmun, and Stevens.

${ }^{91}$ See Caldwell v Mississippi, 472 US 320, 328-29, 341 (1985).

${ }^{92}$ Sawyer, 497 US at 235-36.

${ }^{93}$ Id at $238-41$.

94 Id at 234.

${ }^{95}$ See id at 240-41 (distinguishing a prior state court case because it only addressed the Eighth Amendment significance of a prosecutor's reference to pardon power, not to appellate review).

${ }_{96}$ Id at 236.

97 Id.

93112 S Ct 1130, 1135-40 (1992). The decision in Stringer was 6-3. This time, Justice Souter dissented, joined by Justices Scalia and Thomas.

${ }_{99} 486$ US 356 (1988). 
sissippi $i^{100}$ did not constitute new rules under Teague. Cartwright held that an Oklahoma statute treating an "especially heinous, atrocious, or cruel" killing as an aggravating circumstance was unconstitutionally vague and therefore invalid under the Eighth Amendment. ${ }^{101}$ Clemons mandated that when a state allows the jury to determine a capital sentence by weighing aggravating and mitigating factors, it must conduct at least harmless-error analysis on review if one of the aggravating factors is found constitutionally invalid. ${ }^{102}$

In Stringer, the Mississippi state courts had automatically affirmed Stringer's death sentence, even after invalidating the aggravating circumstance of an "especially heinous, atrocious, or cruel" killing, because the jury had found other aggravating circumstances. ${ }^{103}$ Although the Mississippi statutory scheme directed the jury to weigh aggravating and mitigating circumstances, the state courts did not reconsider the balance after eliminating the unconstitutional element, nor did they determine that including the invalid factor was harmless error; they simply affirmed. ${ }^{104}$ On habeas review, the Fifth Circuit affirmed the state court rulings, ${ }^{105}$ but its decision was vacated and the case was scheduled for rehearing after the Supreme Court's decision in Clemons. On rehearing, the Fifth Circuit held that neither Clemons nor Cartwright should apply retroactively to Stringer, since they were new rules for the purposes of Teague. ${ }^{106}$

In the Supreme Court, Mississippi argued that Clemons was a new rule because Zant $v$ Stephens ${ }^{107}$ had allowed a Georgia state court to affirm a death sentence automatically when one of several aggravating factors was invalidated. Georgia's capital sentencing scheme did not require the jury to weigh aggravating and mitigating factors; thus Stephens left open the question whether automatic affirmance would also be proper in a "weighing" state like Mississippi. The Stringer majority disagreed and held, over a dissent by Justice Souter, that the reasoning of prior capital cases should have alerted the state courts that Mississippi's sentencing scheme would be treated differently than

\footnotetext{
100494 US 738 (1990).

101486 US at 359-60.

102494 US at 752-54.

${ }^{103}$ Stringer, $112 \mathrm{~S} \mathrm{Ct}$ at 1139.

${ }^{104}$ Id.

${ }^{105}$ Stringer $v$ Black, 862 F2d 1108 (5th Cir 1988).

${ }^{106}$ Stringer v Black, 909 F2d 111 (5th Cir 1990).

107462 US 862 (1983).
} 
Georgia's. ${ }^{108}$ Despite the Court's acknowledgment that an old decision could create a new rule if "applied in a novel setting," ${ }^{109}$ Stringer broadly construed the principles in prior capital sentencing cases. The Court did not offer a particular case on point, but relied on the "long line of authority setting forth the dual constitutional criteria of precise and individualized sentencing." 110

The Court dismissed the argument that the Fifth Circuit's contrary conclusion demonstrated the reasonableness of Mississippi's position, reversing its premise in Butler that mere disagreement was reasonable disagreement:

The Fifth Circuit's pre-Clemons views are relevant to our inquiry . . but not dispositive. The purpose of the new rule doctrine is to validate reasonable interpretations of existing precedents. Reasonableness, in this as in many other contexts, is an objective standard, and the ultimate decision whether Clemons was dictated by precedent is based on an objective reading of the relevant cases. The short answer to the State's argument is that the Fifth Circuit made a serious mistake .... .11

Like Penry's, Stringer's interpretation of "dictated by precedent" was soon to be occluded. But even as the cases show an overall movement toward a narrow interpretation of "dictated by precedent," the most recent decisions demonstrate that the Court has become increasingly splintered.

The most telling example is Wright $v$ West,${ }^{112}$ decided a few months after Stringer. Although West is not itself a Teague case ${ }^{113}$ the government petitioner in West, drawing on language in Butler that Teague was designed to validate "reasonable, goodfaith interpretations of existing precedents," asserted that Teague should be construed as creating a general deferential standard

$108112 \mathrm{~S} \mathrm{Ct}$ at 1136-40. In dissent, Justice Souter argued that it was not clear that Georgia's sentencing scheme was so different from Mississippi's: "If unguided discretion created no risk of randomness, it was hardly obvious that this risk arose when a vague aggravating circumstance was weighed." Id at 1144. Justice Souter was joined by Justices Scalia and Thomas.

${ }^{109}$ Id at 1135.

110 Id at 1137 .

111 Id at 1140 .

112112 S Ct 2482 (1992).

${ }^{113}$ Justice Souter, however, in a separate concurring opinion, contended that the case should have been decided on Teague grounds. Id at 2500-03 (Souter concurring in the judgment). 
for reviewing state court constructions of federal law. ${ }^{114}$ While the case was decided on other grounds, this proposition provoked five separate opinions, which vented bitter disagreement over the history and purpose of federal habeas corpus ${ }^{115}$ and the nature of the analysis required by Teague. ${ }^{116}$

Last Term, Teague remained a source of difficulty and dissent. In Graham $v$ Collins, the petitioner challenged his Texas death sentence on the ground that the narrow sentencing questions did not allow the jury to consider his youth, family background, and positive character traits as mitigating factors. ${ }^{117}$ Graham relied on Penry for the proposition that an "as applied" challenge to the Texas statute did not ask for a new rule under Teague. ${ }^{118}$ The Court, however, held otherwise. ${ }^{119}$ Writing revisionist history, the Court described Penry as saying that because ment).

${ }^{114}$ See id at 2490 n 8 (plurality opinion); id at 2501 (Souter concurring in the judg-

${ }^{115}$ Justice Thomas's opinion setting forth the judgment of the Court and Justice $O$ 'Connor's concurring opinion rejoin the debate over the history of habeas corpus begun by Paul Bator, 76 Harv L Rev 441 (cited in note 37). Professor Bator's version of habeas history has been challenged by Peller, 16 Harv CR-CL L Rev 579 (cited in note 37). See also Barry Friedman, $A$ Tale of Two Habeas, 73 Minn L Rev 247, 261-73 (1988); Liebman, 92 Colum L Rev at 2041-94 (cited in note 37). For a historical perspective that cuts across the debate and views habeas in context with civil suits against government officials, see Woolhandler, 45 Stan L Rev at 587-629 (cited in note 6).

${ }^{116}$ Justices Thomas and Scalia, together with Chief Justice Rehnquist, expressed their basic sympathy with a vision of Teague encouraging deference to state court interpretations of federal law. West, 112 S Ct at 2489-91.

Justices Kennedy and O'Connor wrote separately, attempting to enunciate some sensible way of understanding Teague that did not characterize its holding as deference to the legal conclusions of state courts. Id at 2493-98 (O'Connor concurring in the judgment); id at 2498-2500 (Kennedy concurring in the judgment). The effort was not altogether successful. Justice O’Connor argued:

[T] he duty of the federal court in evaluating whether a rule is "new" is not the same as deference; federal courts must make an independent evaluation of the precedent existing at the time the state conviction became final in order to determine whether the case under consideration is meaningfully distinguishable. Teague does not direct federal courts to spend less time or effort scrutinizing the existing federal law, on the ground that they can assume the state courts interpreted it properly.

Id at 2497 ( $O^{\prime}$ Connor concurring in the judgment). She pointed out that the Court had moved away from the view that the "mere existence of conflicting authority" was evidence of legal newness. Id, citing Stringer, $112 \mathrm{~S} \mathrm{Ct}$ at 1140 . The determination of when a rule was "new" under Teague was "objective." Id ( $O^{\prime}$ Connor concurring in the judgment). Justice Kennedy thought that the level of generality at which a rule should be stated for purposes of Teague should vary: "Where the beginning point is a rule of this general application, a rule designed for the specific purpose of evaluating a myriad of factual contexts, it will be the infrequent case that yields a result so novel that it forges a new rule, one not dictated by precedent." Id at 2499 (Kennedy concurring in the judgment).

117113 S Ct 892, 895 (1993).

118 Id at 901 . See also id at 919-20 (Souter dissenting).

21 Id at 901-03. 
Penry's evidence of mental retardation was more aggravating than mitigating under the Texas jury instructions, it "was impossible to give meaningful mitigating effect to Penry's evidence." 120 Thus, the Court claimed Penry stood only for the proposition that states may not exclude mitigating evidence from the jury's consideration, and not for the rule that the state procedures must allow mitigating evidence the full scope of its natural relevance. ${ }^{121}$ Graham's evidence of youth, family background, and positive character traits was distinguishable from Penry's evidence of mental retardation because the jury could have given some mitigating effect to Graham's evidence in considering his future dangerousness. Therefore, Graham was asking for a new rule and his claim was barred by Teague. ${ }^{122}$

The Court has thus backed away from Penry without explicitly overruling it. The Graham court reduced Penry to its specific facts, even suggesting that a broader reading would be unfaithful to Teague. Also, without saying so on the merits, the Court indicated that Lockett and Eddings could (and should) be read only to keep states from excluding mitigating evidence altogether, not to keep states from attenuating its relevance.

The Justices' shifting positions in Graham further demonstrate the Court's confusion about Teague questions. Justice Souter, who had rejected the more lenient view of new rules espoused by Stringer, and Justice O'Connor, the author of the Teague rule, both dissented in Graham. ${ }^{123}$ On the other hand, Stringer's author, Justice Kennedy, joined the Graham majority. And both the majority and the dissent invited the other to eat their earlier words. ${ }^{124}$

The final ruling last term on new rules was Gilmore $v$ Taylor. ${ }^{125}$ Taylor killed his ex-wife's lover in a fight brought on by a dispute over Taylor's visitation of his young daughter. Taylor was convicted of murder and sentenced to thirty-five years in prison. At trial, Taylor testified that he had killed in a burst of sudden and intense passion. In essence, he admitted the elements of murder under Mlinois law while offering the affirmative defense of sudden passion, which by law could reduce his crime

120 Id at 901.

121 Id at 902 .

122 Id at 903.

${ }^{123}$ Id at 917-26 (Souter dissenting, joined by Blackmun, Stevens and O'Connor).

${ }^{124}$ See id at 9,02 (majority citing Justice Souter's dissenting opinion in Stringer); id at 920 (dissent citing Justice Kennedy's opinion in West).

125113 S Ct 2112 (1993). 
to manslaughter. However, because the jury was instructed to consider Taylor's guilt for murder before considering his guilt for manslaughter, it was possible for the jury simply to have stopped deliberating before considering the possibility that Taylor was guilty only of manslaughter. The Seventh Circuit granted relief on the ground that its recent decision in Falconer $v$ Lane, ${ }^{126}$ which had held a conviction invalid when the jury had not been instructed that a finding of certain facts would require reducing the offense to manslaughter, was not a "new" rule for the purposes of Teague. ${ }^{127}$

The Supreme Court reversed, finding that Teague barred the retroactive application of Falconer. ${ }^{128}$ In the process, however, the Court called Falconer itself into serious doubt. An analysis of the lower court's reasoning highlights the Court's narrowing of precedential authority.

The Seventh Circuit had employed a two-element analysis in determining whether the Falconer rule was new. First, because disagreement among courts is a sign of legal newness under Butler, the court considered whether other courts had reached a conclusion contrary to Falconer. ${ }^{129}$ Second, the court asked whether the prior precedent relied upon stated a rule at an appropriate level of generality: "The more general a given set of precedent, the more latent ambiguity inherent in that precedent, and the less likely a subsequent decision is dictated by that precedent-and therefore the more likely it announces a new rule." 130 Interestingly, the question whether Falconer was dictated by prior precedent was not answered by looking to the cases upon which it relied. In fact, the Seventh Circuit in Taylor concluded that the case upon which Falconer actually relied was "too general to have compelled Falconer within the meaning of Teague."131 However, citing Butler's dismissal of the analysis in Roberson, the court noted that "[i]n determining whether a decision is compelled by precedent, we examine not only the precedent the decision actually cites, but also the precedent it could have cited. Self-characterization has never been considered dispositive in Teague new rule analysis."

126905 F2d 1129, 1136 (7th Cir 1990).

127 Taylor v Gilmore, 954 F2d 441, 452-53 (7th Cir 1992).

${ }^{123}$ Taylor, $113 \mathrm{~S}$ Ct at 2119.

129 Taylor, 954 F2d at 446.

$130 \mathrm{Id}$.

131 Id at 452.

${ }^{132} \mathrm{Id}$. 
The Seventh Circuit found two other cases "dictating" the result in Falconer: Boyde $v$ California ${ }^{133}$ and Connecticut $v$ Johnson. ${ }^{134}$ In a tidy piece of deduction, the court took the jury instruction test from Boyde (whether a "reasonable likelihood" existed that the jury had applied the instruction in an invalid manner) and the substantive rule from Johnson (jury instructions that create an erroneous presumption concerning a mitigating state of mind are invalid), and concluded that Falconer was dictated by the two cases. ${ }^{135}$

The Supreme Court disagreed. It noted that Boyde was a capital case and had given no indication that a jury instruction altering consideration of mitigating evidence could amount to a due process violation outside that context. ${ }^{136}$ Although Boyde did not limit its holding to capital cases, the Court apparently thought state courts could reasonably distinguish Boyde on this basis. ${ }^{137}$

Taylor also relied on cases guaranteeing "criminal defendants 'a meaningful opportunity to present a complete defense."'138 The Court distinguished these cases as not having involved "restrictions imposed on a defendant's ability to present an affirmative defense."139 Therefore, the Court held, the principle Taylor invoked was too general "to provide any meaningful guidance for purposes of our Teague inquiry."140

Curiously, regardless of all the rhetoric concerning the "reasonableness" of the state courts' interpretations of precedent in Taylor, the state courts had not actually adopted any of the arguments or distinctions the Court discussed. ${ }^{141}$ Rather than ad-

${ }^{133} 494$ US 370 (1990).

134460 US 73 (1983).

135 Taylor, 954 F2d at 453.

${ }^{136}$ Taylor, $113 \mathrm{~S} \mathrm{Ct}$ at 2118. Justice O'Connor concurred separately to disagree with this reading of Boyde. She also chided the majority for "reach[ing] out to decide the merits of the rule" and "constru[ing] our cases so narrowly." Id at 2120.

${ }^{137}$ See id at 2117-18.

${ }^{138}$ Id at 2118, quoting Crane $v$ Kentucky, 476 US 683, 690 (1986).

139 Taylor, $113 \mathrm{~S}$ Ct at 2118.

140 Id at 2119. Chief Justice Rehnquist, writing for four of the majority Justices in Taylor (himself, Scalia, Thomas, and Kennedy), then dropped a footnote adhering to his view, expressed in Butler, that the existence of disagreement is evidence of "newness." Id at $2119 \mathrm{n} \mathrm{3}$. Here, he asserted the fact that these jury instructions had been used in Mllinois for 20 years was "strong evidence of the reasonableness of the interpretations given existing precedent by state courts." Id. Justice Souter joined the majority opinion but refused to join the footnote, having previously taken the position that existence of disagreement is not necessarily evidence of reasonable disagreement in his dissent in Groham, $113 \mathrm{~S}$ Ct at 918 (Souter dissenting).

${ }^{141}$ The Illinois Supreme Court had since questioned the validity of the jury instruction 
dressing the actual basis for their holdings, the Court instead invented "reasonable" arguments based on earlier cases the state courts might have relied upon. This bend-over-backwards deference resembles inventing rational bases not articulated by state legislatures in order to uphold state statutes against equal protection attacks. ${ }^{142}$

This Term has yielded the latest pronouncement on new rules. Returning to the positive law approach to precedent adopted in Teague itself, Justice O'Connor garnered eight votes for her analysis in Caspari $v$ Bohlen. ${ }^{143}$

Bohlen had initially been sentenced as a "persistent offender" under a Missouri statute that gave trial judges the sentencing prerogative (instead of the jury) for offenders proved beyond a reasonable doubt to have been guilty of two or more previous felonies. ${ }^{144}$ On appeal, the Missouri Court of Appeals reversed the persistent offender finding on the ground that the prior crimes had not been proven and remanded for a second sentencing proceeding, in which the finding was reinstated. Bohlen argued before the state court in a second round of appeals, and again on federal habeas, that the Double Jeopardy Clause barred the state from having a second chance to prove the prior felonies. The state court rejected Bohlen's claim, as did the federal district court. ${ }^{145}$

The Eighth Circuit reversed, relying on the Supreme Court's holding in Bullington $v$ Missouri. ${ }^{146}$ Bullington held that a state cannot hold a second trial-like death penalty sentencing hearing

on state law grounds, see People v Bolden, 132 Ill App 3d 1047, 477 NE2d 1380, 1387-88 (1980) (Bolden $I$ ), but Taylor did not get the benefit of that decision on direct appeal, because the Illinois Appellate Court held he had waived any objection by failing to make it contemporaneously. People v Taylor, $181 \mathrm{Ill}$ App 3d 538, 536 NE2d 1312, 1313 (1989). Following the initial affirmance of Taylor's conviction, however, the Illinois Supreme Court declared that failure to give proper jury instructions under Bolden $I$ was "grave error," and objections could not be waived. People $v$ Reddick, 123 Ill 2d 184, 526 NE2d 141, 147 (1988). Yet the Illinois Appellate Court later decided that this error, though "grave," was not constitutional error, and thus the court would not reach the issue of the improper jury instruction in Taylor's habeas proceedings. Taylor, $536 \mathrm{NE2d}$ at 1313. See also People v Bolden, $181 \mathrm{Il}$ App 3d 481, 536 NE2d 1308, 1310-11 (1989) (Bolden II).

${ }_{142}$ See, for example, Nordlinger $v$ Hahn, 112 S Ct 2326, 2332 (1992).

${ }^{143} 114$ S Ct 948 (1994). Justice Stevens was the lone dissenter.

144 $114 \mathrm{~S} \mathrm{Ct}$ at 951 . Apparently in most cases the finding that one is a "persistent offender" also makes one liable for an increased penalty, as the Eighth Circuit, 979 F2d 109,113 (8th Cir 1992), and Justice Stevens in dissent, $114 \mathrm{~S} \mathrm{Ct}$ at 957 point out. For

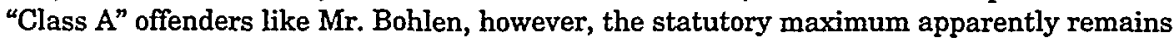
the same. Mo Rev Stat § 558.016.7 (1992); $114 \mathrm{~S} \mathrm{Ct}$ at 951.

$145114 \mathrm{~S}$ Ct at 952.

146451 US 430 (1981). 
for the same crime if a sentencing jury has already once rejected the death sentence. Because the Missouri "persistent offender" statute, like the death penalty sentencing procedure in Bullington, required a "trial-like" proceeding and findings "beyond a reasonable doubt," the Eighth Circuit concluded that Bullington "dictated" reversal of the sentence in Bohlen's case and was therefore not a "new rule."

The Supreme Court, however, disagreed. First, the Court noted that resentencing generally does not implicate Double Jeopardy concerns. Then, relying on language in a footnote in Bullington that "sentencing proceedings for capital cases . . . are unique," non-capital cases would be a "new rule," not dictated by the prior cases. ${ }^{149}$

As in Teague itself, the Court relied on limiting language in its prior opinions without asking whether the distinction stated made a difference. In fact, the Bullington decision clearly turns on whether a sentencing procedure is "trial like," not whether or not it is capital. ${ }^{150}$ Capital sentencing is treated differently in Bullington because it is more trial-like and the sentencer's discretion is confined, not because it is capital. Yet, the Court in Bohlen never explains why a reasonable state court judge would think that the capital/non-capital distinction was a distinction with a difference. The fact that there was isolated, and in fact acontextual, language in Bullington drawing that distinction was held to be sufficient. ${ }^{151}$

The Court's reluctance to ask whether such a distinction is reasonable in the context probably stems from a reluctance to express any view on the merits of Bohlen's claim. ${ }^{152}$ Yet this

147 Bohlen v Caspari, 979 F2d 109 (8th Cir 1992).

148 Bullington, 451 US at $441 \mathrm{n} 15$.

$149114 \mathrm{~S} \mathrm{Ct}$ at 956.

150 Bullington, 451 US at $438-45$.

151 This is not to say that the Court's Double Jeopardy cases prove the Eighth Circuit was correct. There is a lot of tension between United States $v$ DiFrancesco, 449 US 117 (1980), which upheld the constitutionality of government appeals under a federal recidivist statute similar to Missouri's, and Bullington. But Bullington did not distinguish DiFrancesco on the ground that it involved a non-capital sentence. Bullington, 451 US at 440-41. Nor does the Bohlen Court explain why that distinction makes a difference.

The Bohlen Court's reliance on the per curiam opinion in Pennsylvania $v$ Goldhammer, 474 US 28 (1985), is also troubling. There, the capital/non-capital distinction was added by brackets to a quotation from DiFrancesco, again, entirely without explanation. Id at 30 .

152 See Bohlen, $114 \mathrm{~S} \mathrm{Ct}$ at 955 ("While our cases may not have foreclosed the application of the Double Jeopardy Clause to noncapital sentencing, neither did any of them 
perhaps laudable objective leads again to the position that any distinction will make a new rule. The Court here does at least look for that distinction somewhere in prior cases, but the Court's reliance on an out-of-context remark in Bullington gives pretty wide range for "finding" distinguishing language.

Despite fits and starts, the "new rule" analysis set out in Butler seems to be winning the day. The two "outlier" cases, Penry and Stringer, that read the "rule" of prior precedents more broadly, are therefore unlikely to enjoy continued application. Graham has limited Penry to its facts, while Stringer's analysis appears to conflict with its own author's previous statements in Sawyer and subsequent joinder in Graham and Taylor. Further, Stringer is also a narrow ruling requiring only harmless-error review; it is unlikely to expand to any other areas. ${ }^{153}$

While the decisions are moving toward the narrowest possible definition of a what precedent dictates, the members of the Court do not sit comfortably with this development. The majorities shift and change, and the separate opinions in these cases fill the United States Reports.

\section{What's New?}

The Court's discomfort is warranted. When the applications of Teague are distilled, a disturbing account of judging and precedent emerges. As the above discussion of the Teague cases shows, the following principles capture the Court's analysis of what rules are "dictated by precedent":

- A rule is not "dictated by precedent" unless it falls within a narrow description of the facts and outcomes of prior decisions. ${ }^{154}$

apply the Clause in that context.").

${ }_{153}$ See Karl N. Metzner, Anatomy of an Upset: The Supreme Court's Shocker on Habeas Retroactivity, 28 Crim L Bul 521, 550-53 (1992).

${ }^{154}$ See Graham, $113 \mathrm{~S} \mathrm{Ct}$ at 902 ('Even if Graham's evidence, like Penry's, had significance beyond the scope of the first special issue, it is apparent that Graham's evidence-unlike Penry's-had mitigating relevance to the second special issue concerning his likelihood of future dangerousness .... This distinction leads us to conclude that neither Penry nor any of its predecessors 'dictates' the relief Graham seeks within the meaning required by Teague."); Sawyer, 497 US at 236 ("We do not doubt that our earlier Eighth Amendment cases lent general support to the conclusion reached in Caldwell. But neither this fact, nor petitioner's contention that state courts 'would have found Caldwell to be a predictable development in Eighth Amendment law, ... . suffices to show that Caldwell was not a new rule. In petitioner's view, Caldwell was dictated by the principle of reliability in capital sentencing. But the test would be meaningless if applied at this 
- The Court's own characterization of its holding as dictated by precedent does not mean it was in fact dictated by precedent. $^{155}$

- The existence of a conflict of authority is prima facie evidence that a rule is not dictated by precedent. ${ }^{256}$

- A rule is not dictated by precedent if reasonable state court judges could disagree as to the proper rule. ${ }^{157}$

Further, in determining what constitutes "reasonable" disagreement, the Court has made clear:

- A court may construct a "reasonable" disagreement for Teague purposes independent of the analysis of precedent adopted by the state court itself. ${ }^{158}$

- A case may be reasonably distinguished on the basis of facts not considered relevant by the prior court. ${ }^{159}$

- A reasonable interpretation of precedent may ignore distinctions drawn in prior opinions. ${ }^{160}$

level of generality."); Taylor, $113 \mathrm{~S} \mathrm{Ct}$ at 2118 ("We have previously stated that the Constitution guarantees criminal defendants 'a meaningful opportunity to present a complete defense.' But the cases in which we have invoked this principle dealt with the exclusion of evidence or the testimony of defense witnesses. None of them involved restrictions imposed on a defendant's ability to present an affirmative defense.") (citations omitted). Also, compare the Parks majority's strict reading of claim and precedent, 494 US at 488-94, with that of the dissent. Id at 498-505.

${ }_{155}$ Butler, 494 US at 415 ("[T] $]$ he fact that a court says its decision is within the logical compass' of an earlier decision, or indeed that it is 'controlled' by a prior decision, is not conclusive for the purposes of deciding whether the current decision is a 'new rule' under Teague.").

156 Compare Butler, 494 US at 415, and Taylor, $113 \mathrm{~S} \mathrm{Ct}$ at $2119 \mathrm{n} 3$ (only four Justices joining in this footnote), with Stringer, 112 S Ct at 1139-40, West, 112 S Ct at 2497 (O'Connor concurring in the judgment), and Graham, $113 \mathrm{~S} \mathrm{Ct}$ at 918 (Souter dissenting).

${ }^{157}$ Butler, 494 US at 415.

158 West, $112 \mathrm{~S} \mathrm{Ct}$ at 2500 (Souter concurring in the judgment) (no opinion on the merits in the state courts); Taylor, 113 S Ct at 217-18 (no opinion on the merits in the state courts).

${ }^{159}$ Butler, 494 US at 414-15 (state courts were entitled to make a distinction between being reinterrogated about the same crime and being reinterrogated about a different crime, a distinction not made in Edwards); Taylor, $113 \mathrm{~S} \mathrm{Ct}$ at 2117-18 (state courts were entitled to distinguish Boyde as applying only to capital cases, even though Boyde did not say it was so limited).

160 See Sawyer, 497 US at 248-49 (Marshall dissenting) (pointing out that the state had ignored the distinction between accurate and inaccurate prosecutorial comment, a 
- An interpretation of precedent may be reasonable even if it conflicts with the rule articulated in the precedent. ${ }^{161}$

Taken together, these propositions suggest that a new rule arises in any case that can be reasonably distinguished on its facts from prior cases. However, the boundaries of the reasonable are rather permeable: the prior court's own statements of the rule, of the material facts, and of the rule's relation to prior precedent are all not determinative.

The "holding" of the prior case is thus a moving target, from which no deduction or "dictation" is possible. No bright-line test of newness can avoid this slippery slope-if the holdings of cases will not sit still, they cannot be cleaved into new ones and old ones by any analysis, no matter how fine. ${ }^{162}$ Even the obvious "bright line" that new rules are limited to outright overrulings fades when a prior decision's holding can be characterized at various levels of generality. Couching the holding of a prior case in general terms makes it more likely to be overruled; couching the holding in fact-specific terms makes it impossible to overrule. And if state courts are allowed to reinterpret the holdings of precedents, practically every judicial decision can be characterized as a new rule-whatever line is used to divide new from old.

More importantly, the Court's division of new law from old undermines all judicial decision making. If, as the "dictated by

distinction expressly made in a prior opinion); Parks, 494 US at 493-94 (finding no need to employ a distinction between emotional responses based on evidence and emotional responses not based on evidence, even though one had been made in a prior case). But see Stringer, $112 \mathrm{~S} \mathrm{Ct}$ at 1138-40 (stating the state should have distinguished between weighing states and non-weighing states, though precedent left.the question open).

161 Sawyer, 497 US at 237 ('The Mississippi Court's characterization of Ramos, of course, later proved to be incorrect. But this nonetheless suggests that prior to Caldwell our cases did not put other courts on notice that the Eighth Amendment compelled the Caldwell result."). See also Butler, 494 US at 415.

${ }_{162}$ Compare Eisenberg, The Nature of the Common Law at 51 (cited in note 13) ("As a practical matter, the force of the principle of stare decisis is inversely related to the extent of the deciding court's discretion to determine what rule a precedent stands for.").

Because the "rule" of a prior case is fluid, the recommendation of many commentators that the Court simply change the place at which it draws the new rule-old rule line seems not to solve the problem. See, for example, Fallon and Meltzer, 104 Harv L Rev at 1796 (cited in note 6) (arguing new is something less than not "clearly foreshadowed" by precedent); James B. Haddad, The Finality Distinction in Supreme Court Retroactivity Analysis: An Inadequate Surrogate for Modification of the Scope of Federal Habeas Corpus, $79 \mathrm{Nw}$ U L Rev 1062, 1064 (1984-85) (arguing a rule should be considered "new" only if the Supreme Court has overruled a case upon which a litigant relied); Hoffmann, 1990 BYU L Rev at 210-13 (cited in note 6) (advocating a test of newness like that proposed by Justice Harlan in Desist: answering the newness question through a "careful analysis of extensions of prior cases"). 
precedent" test assumes, every case that can be factually distinguished from prior cases is "new" and thus violates reasonable reliance interests, most of what judges do must unfairly surprise litigants. The justification for applying such "new" law to any already existing controversy is seriously undermined. All adjudication begins to seem unfairly retroactive and arbitrary. Precedent itself seems somewhat irrelevant-decisions are new, even when they purport to rely on prior caselaw.

Is the Court really of the view that its own opinions are so much insignificant sound and fury, preserving only an appearance of reason and fairness? Members of the Court at times speak this way, treating the idea of "following precedent" as no more than a rhetorical flourish that serves to legitimate adjudication in the eyes of a naive public: "In a system based on precedent and stare decisis, it is the tradition to find each decision 'inherent' in earlier cases (however well concealed its presence might have been) ...." "163

Indeed, the Teague cases have a strange tenor; as Professor Althouse observes, the players draw attention to the fact that their performance is only a play. ${ }^{164}$ This ironic self-deprecation is inevitable because no independent standard can evaluate the "newness" of legal doctrine: to say that a decision does not follow from precedent is, within the practice of adjudication itself, to say that it is wrong. Hence, the current Teague inquiry reveals the Court's split personality, with Justice Mr. Hyde in the Teague case undermining the reasoning of Justice Dr. Jekyll in the case on the merits. This duality is most apparent in Butler, which had to adopt a different reading of the same precedent than the Court's own reading two years earlier in Roberson. ${ }^{165}$

163 Penry, 492 US at 353 (Scalia concurring in part and dissenting in part). See also Butler, 494 US at 415 ("Courts frequently view their decisions as being 'controlled' or 'governed' by prior opinions even when aware of reasonable contrary conclusions reached by other courts."); Beam, 111 S Ct at 2451 (Scalia concurring in the judgment) ("I am not so naive (nor do I think our forbears were) as to be unaware that judges in a real sense 'make' law. But they make it as judges make it, which is to say as though they were 'finding' it-discerning what the law is, rather than decreeing what it is today changed to, or what it will tomorrow be.").

${ }_{164}$ Althouse, 1991 Wis L Rev at 963-66 (cited in note 6).

${ }_{165}$ See text accompanying notes 74-77. It is interesting to note that the Court has expressly avoided such "double-talk" in the context of determining whether a legal position is frivolous under Rule 11. In Cooter \& Gell v Hartmarx, 496 US 384, 403-404 (1990), the Court settled on an abuse of discretion standard for reviewing district court impositions of Rule 11 sanctions. A de novo standard, the Court feared, would require appellate courts to state not what the law is, but what the law might reasonably be construed to be, "establishing circuit law in 'a most peculiar, second-handed fashion." Id at 404, quoting Pierce $v$ 
More troubling still is the possibility that the Court will reunify its split personality by adopting Teague's view of precedent-in which virtually no case follows from prior cases-for decisions on the merits, when retroactivity is not an issue. To "follow precedent" in a decision on the merits using Teague's standard would mean that no relief may be granted unless a result is "dictated by precedent" in the Teague sense. As illustrated by the Teague cases, this requirement would be tantamount to saying that no relief may be given at all, because nearly any case can be factually distinguished from prior cases.

This danger materialized this past Term when Johnson $v$ Texas, ${ }^{166}$ a case on the merits, relied on Graham, a Teague case decided four months earlier. After the Graham Court had reinterpreted Penry to show that it did not "dictate" a rule requiring Texas courts to give a special instruction requiring that deathpenalty juries consider a defendant's youth as a factor mitigating blameworthiness, the resolution of the same question on direct review in Johnson became a foregone conclusion. ${ }^{167}$ Over the vehement objections of Justice O'Connor, Teague's own founder, the majority referred to Graham's interpretation of what was "dictated by precedent" to decide Johnson: "We confirmed this limited view of Penry and its scope in Graham v. Collins."168

Thus, Teague's distorted view of precedent has infected substantive constitutional law. ${ }^{169}$ Teague has begun to leak.

\section{The RoOT OF THE PROBLEM}

The new rule cases clearly indicate that no case can be "dictated" by precedent unless the precedent contains a static, some-

\footnotetext{
Underwood, 487 US 552, 561 (1988).

166113 S Ct 2658 (1993).

167 Id at 2667-70.

168 Id at 2668.
}

${ }^{169}$ One commentator has cautioned that lower courts easily confuse a Teague inquiry with a merits inquiry, reading the Supreme Court's Teague opinions as substantive analysis of the right at stake. "By stressing the novelty of an established constitutional rule in a rearguard case, the Supreme Court weakens that rule's precedential foundation and thereby discourages extensions of the rule while simultaneously encouraging its restrictive application." Dubber, 30 Am Crim L Rev at 32-33 (cited in note 1).

The dissenters in Johnson $v$ Texas also lamented the Court's confusion. The majority, they argued, confused the merits inquiry with the Teague inquiry: "When determining whether a rule is new, we do not ask whether it fairly can be discerned from our precedents; we do not even ask if most reasonable jurists would have discerned it from our precedents. We ask only whether the result was dictated by past cases, or whether it is 'susceptible to debate among reasonable minds ...." $113 \mathrm{~S} \mathrm{Ct}$ at 2675 (O'Connor dissenting, joined by Blackmun, Stevens, and Souter). 
what general statement of a rule from which applications of the rule may be deduced. But the Court does not treat its opinions as announcing such static general rules. Instead, it denounces attempts to issue general rules in its opinions as "dicta" worded too broadly to govern. Consequently, no case can be "dictated" by precedent, and Teague's attempt to find a clean line between new and old cases ends in confusion and even hypocrisy.

What has gone wrong in the Teague cases? Simply this: the Court has tried to mix oil and water. Marking off decisions as new and old is incompatible with the traditional distinction between holding and dicta, which does not delimit a case's precedential value by the court's actual language, but allows a case's significance to emerge over time as it is tested and refined in different contexts. This incompatibility runs deep. The assumptions about the nature of law and judging that allow for the new/old distinction are directly contrary to the assumptions about the nature of law and judging that allow for the holding/dicta distinction. The new/old dichotomy, which assumes that legal rules are either new creations or deducible from prior precedent, relies on positive law theory. In contrast, the holding/dicta dichotomy, which assumes that the Court's opinions can be reassessed and reinterpreted, relies on common law theory.

\section{A. Positive Law}

From the positive law standpoint, law exists as the "intention" of the duly constituted authority; because a rule is law only by virtue of its source. ${ }^{170}$ The lawgiver determines the law; therefore, laws are merely manifestations of the lawgiver's will. More simply, law is will. ${ }^{171}$ Changes in law must be understood

170 For the essential difference of a positive law (or the difference that severs it from a law which is not a positive law) may be stated thus. Every positive law, or every law simply and strictly so called, is set by a sovereign person, or a sovereign body of persons, to a member or members of the independent political society wherein that person or body is sovereign or supreme. Or (changing the expression) it is set by a monarch, or sovereign number, to a person or persons in a state of subjection to its author.

John Austin, The Province of Jurisprudence Determined (1832), reprinted in John Austin, The Province of Jurisprudence Determined and The Uses of the Study of Jurisprudence 132 (Noonday, 1954). See also Frederick Schauer, Constitutional Positivism, 25 Conn L Rev 797,799 (1993) (Legal positivism takes the position that the law "is not derived necessarily from fundamental moral principles, but rather is simply 'posited' by human beings and human institutions."), and the bibliography of major theorists cited therein. Id at $799 \mathrm{n} 3$.

171 Every law or rule ... is a command. 
as changes in will, hence the emphasis on "framer's intent." Interpreting intention as a physical, psychological event is consonant with positive law's scientific pretensions. ${ }^{173}$ However, because statements of law are only evidence of this intent, not the intent itself, interpretation's goal is to find out what the lawgiver intended.

Positive law also assumes that, because the law does not exist as law before its creation, it is unknowable until announced by the lawgiver. Those subject to the law rely on the statement of the law to guide their actions. From this perspective, subjects need not only an authoritative lawgiver, but an authoritative procedure for lawgiving-a rule for recognizing which rules are law. ${ }^{174}$ One cannot expect the subject to determine the framer's

If you express or intimate a wish that I shall do or forbear from some act, and if you will visit me with an evil in case I comply not with your wish, the expression or intimation of your wish is a command.

...

Being liable to evil from you if I comply not with a wish which you signify, I am bound or obliged by your command, or I lie under a duty to obey it.

Austin, The Province of Jurisprudence at 13-14. See also Philippe Nonet, What is Positive Law?, 100 Yale L J 667, 668-70 (1990) (positive law equates authority with will to power).

172 Some would define positivism solely in terms of a potential or actual separation between law and other modes of decision making (whether moral, economic, aesthetic, or otherwise), with no necessary ties to theories of "framer's intent." See, for example, Frederick Schauer, Playing by the Rules 196-200, 218-21 (Oxford, 1991). However, no bright line between law and these other methods of decision making can be drawn without recourse to some (arbitrary) act of will to distinguish law from non-law. Eliminating the idea of an arbitrary and authoritative source for law and instead defining positivism as the view that law is a separate custom than other customs would also eliminate the clarity of the law/non-law distinction-customs are notoriously indefinite. A decision maker or an arbitrary procedure is necessary in order to create the clear and certain distinction between law and non-law that positivism requires. In any event, Austin's original term "positivism" related to the "positing" of laws, not just their potential for being separately categorized. This clearly derives the authority of law from the will of the legislator.

${ }_{173}$ The drive toward a more "scientific" study of law is apparent in nearly all theories of positive law, because such study purges law of normative elements to make it more amenable to pure description. See Austin, Province of Jurisprudence at 2 ("The principal purpose or scope of the six ensuing lectures, is to distinguish positive laws (the appropriate matter of jurisprudence) from the objects now enumerated [morality, divine law, laws of nature]: objects with which they are connected by ties of resemblance and analogy; with which they are further connected by the common name of 'laws'; and with which, therefore, they often are blended and confounded."); Hans Kelsen, Anders Wedberg trans, General Theory of Law and State 14-15 (Harvard, 1945) (attempting to isolate and characterize law so that it is amenable to social scientific study); H.L.A. Hart, The Concept of Law 96 (Oxford, 1961) ("There is a constant pull towards an analysis of legal concepts] in the terms of ordinary or 'scientific,' fact-stating or predictive discourse.").

174 In order that an obligation may be effectual ... two conditions must concur. [First, i]t is necessary that the party should know the law, by which the obligation is im- 
intention telepathically; the lawgiver must promulgate the law. Law, as promulgated, exists as marks on paper, magnetic or digital codes, or the words spoken on the proper ceremonial occasion by the duly recognized lawgiver. Law is now the physical ink on paper in the dusty books of a library. ${ }^{175}$

A change in law is signaled by a change (through authoritative procedures) of some physical document or database. Law has physical existence. For example, an inadvertent error in a statutory document can only be remedied by a second statutory document that amends the first. Laws, therefore, exist and change in the same way in which physical objects change. And like objects, laws can be new or old.

Accordingly, in a positive law framework, interpretation of precedent should operate like statutory construction. A lower court should be bound by the intentions of its superior, as reflected in the words printed in the official reporter. The rules articulated by the higher court in its entire opinion should be considered authoritative as enunciated. ${ }^{176}$

The positive law standpoint cannot distinguish between statements necessary to the holding (which carry precedential force) and statements that are only dicta (digressions or unneces-

posed, and to which the sanction is annexed. [Second, i]t is necessary that he should actually know (or, by due attention or advertence, might actually know) that the given act, or the given forbearance or omission, would violate the law, or amount to a breach of the obligation. Unless these conditions concur, it is impossible that the sanction should operate upon his desires.

John Austin, 2 Lectures on Jurisprudence 169 (Murray, 1863) (emphasis omitted). See also Hart, The Concept of Law at 92 (identifying the need for "rules of recognition" which "will specify some feature or features[, the] possession of which by a suggested rule is taken as a conclusive affirmative indication that it is a rule of the group[,] to be supported by the social pressure it exerts").

175 For example, taking the view that law is an object, one commentator "refutes" the view (usually attributed to Blackstone) that "a legal principle which was once announced and once existed can later be said never to have existed at all," arguing that "the principle can still be viewed in permanently bound books, on microfiche and CD-ROM, and in computerized retrieval systems." Michael B. Dashjian, The Prospective Application of Judicial Legislation, 24 Pac L J 317, 370 (1993).

${ }^{176}$ See Larry Alexander, Constrained by Precedent, 63 S Cal L Rev 1, 5, 17-18 (1989) (presenting as "the only reasonable alternative" the "rule model" of precedent, in which "the precedent court has authority not only to decide the case before it but also to promulgate a general rule binding on courts of subordinate and equal rank [and in which the rule will operate like a statute and will, like a statute, have a canonical formulation"); Antonin Scalia, The Rule of Law as a Law of Rules, 56 U Chi L Rev 1175, 1179-80 (1989) (arguing that Supreme Court Justices should strive to articulate clear rules to guide lower courts); Henry P. Monaghan, Taking Supreme Court Opinions Seriously, 39 Md L Rev 1, 1-12 (1979) (suggesting that the Court should move towards giving its own statements of rules more weight). See also United States $v$ Stanley, 482 US 669, 680 (1987) (refusing to distinguish a prior case on its facts) (per Scalia). 
sary context). The official judge-lawgiver announces both through the same official procedures. Both have the necessary indicia of validity. Moreover, making a distinction between holding and dicta requires picking and choosing which reason best supports the court's result. Subjects of a positive law regime cannot legitimately pick and choose among reasons, because they are presumed not to know the law until it is given to them. Thus, they have no criterion outside the opinion itself to use in sifting holding from dicta. ${ }^{177}$ Indeed, the common law idea that a judge need not even explicitly state her holding runs entirely contrary to positive law presuppositions.

Positive law must also presume that general guidelines for proper action adequately determine the results of particular cases. Otherwise, subjects would be unable to apply the general laws enunciated by the sovereign. And positive law further assumes that a law has a clear "core" of application, outside any particular context. For if the content of the law were determined by context or legislative history, the careful delineation of law from non-law

17 Austin appears to acknowledge the holding/dicta distinction when he discusses judge-made law: "[T]he general propositions which occur in a judicial decision, must always be taken with reference to the specific peculiarities of the case. For, as the proper purpose of the judge is the decision of the specific case, any general proposition which does not properly concern it, is extra-judicial and unauthoritative." Austin, 2 Lectures on Jurisprudence at 328 (cited in note 174). However, he never explains what criteria guide this "delicate and difficult" process, and is troubled by the result that "we can never be absolutely certain (so far as I know) that any judiciary law is good or valid law." Id at 366, 371. Consequently, Austin proposes that all judicial law be codified: "[T]here can be no doubt that a complete code is better than a body of judicial law .... [A] mere statement of the evils inherent in judiciary law is amply sufficient to demonstrate ... that codification is expedient." Id at 372-73. Thus, he comes around to saying that the only good and valid law is law laid down as general principles by sovereign authorities. If judges have the authority to make law, it ought to be codified into general principles; otherwise it is too uncertain. A pure theory of positive law would insist, it seems to me, that judges couch their decisions in terms of general rules and that their entire opinions be authoritative.

Hart would adjust his "rule of recognition" to take into account the fact that not everything a judge says in an opinion is law: "Unlike an authoritative text or a statute book, judgments may not be couched in general terms and their use as authoritative guides to the rules depends on a somewhat shaky inference from particular decisions, and the reliability of this must fluctuate both with the skill of the interpreter and the consistency of the judges." Hart, Concept of Law at 95 (cited in note 173). However, as there is no clear rule of recognition for determining the authoritativeness of legal decisions, the subject reading the decision must be deriving the criteria of legality from unauthorized or customary sources. As Hart acknowledges that the ultimate source of authority is a rule of recognition that is not itself the product of a sovereign, but is upheld only by customary obedience, id at 106-07, he need not assume that the subjects do not know the law until it is announced, nor that subjects are surprised by what courts do. In the final analysis, he begins to sound less and less like a legal positivist. 
made by the rules of recognition would be circumvented, and the subject allowed to derive the law from unauthorized sources.

Consequently, adjudication is often pictured as the application of the "core" meaning of an authoritatively promulgated rule. Judges create new rules only in the shadowy crevices (penumbral interstices) of the existing rules. Because judges may disagree about what laws should be made in these peripheral cases, appellate review is necessary to provide a "last word"-an authoritative statement of the law. Hence, from the positive law perspective, there are new rules and old rules. A judicial decision must either apply the core meaning of an old rule, or promulgate a new rule where the old rule's clear center leaves off. ${ }^{178}$

This view also presupposes that prior judicial opinions are to be treated like statutes. The rules enunciated in prior opinions have a clear "core," a "plain meaning" that can be applied to subsequent cases. When the "core" is applied in a second case, the litigants and lower courts should not be surprised; the meaning was clear from the prior case. Retroactive application, therefore, violates no expectations. When a penumbral case is decided, however, the higher court "makes law" and litigants and lower courts cannot be expected to anticipate the decision. In these cases, retroactive application does violate expectations, and prospective application is more appropriate. ${ }^{179}$

A positive law standpoint, then, explains the distinction between new and old rules, but not the distinction between dicta and holding. Laws are new or old depending on their date of promulgation and whether they are core applications of old rules or penumbral judicial lawmaking. The distinction between dicta and holding, however, does not make sense from the standpoint of positive law. Every articulation of a rule by an official is valid, and later interpreters are not allowed to pick and choose or second guess the plain language of the opinion.

178 This distinction has become famous, or perhaps infamous, in the debate between H.L.A. Hart and Lon Fuller, later joined by Ronald Dworkin. See H.L.A. Hart, Positivism and the Separation of Law and Morals, 71 Harv L Rev 593, 606-08 (1958); Lon Fuller, Positivism and Fidelity to Law-A Reply to Professor Hart, 71 Harv L Rev 630, 661-69 (1958); Ronald Dworkin, Taking Rights Seriously 58-64 (Harvard, 1977); Ronald Dworkin, Law's Empire 6-44 (Harvard, 1986).

179 "In relation to the decided case by which the rule is introduced, a rule of judiciary law is always (strictly speaking) and often in its practical effect, an ex post facto law." Austin, 2 Lectures on Jurisprudence at 361 (cited in note 174). See also Hart, Concept of Law at 128-30 (cited in note 173). 


\section{B. Common Law}

In contrast to the positive law framework, common law does not hang on the exact words of an opinion. The words, even of a duly appointed Article III court, are not themselves law, even when promulgated in the official reports of opinions of the court. They may be dicta. Skillful judges and lawyers capture the reason and result of a series of opinions; that is, they view the cases as a coherent series, rather than as the disconnected and even contradictory pronouncements they may appear to be. Law, then, is not the will of earlier judges, nor the words on the pages of their opinions. Law, from the standpoint of the common law judge, is the coherence, sense, and significance of a set of human actions. ${ }^{180}$

Consequently, the most traditional understanding of the common law doctrine of precedent does not locate the binding power of a prior case in its author's intention or words. ${ }^{181}$ Instead, the "material facts" and the result of a case guide later decisions. The later court evaluates whether the material or "important" facts in the prior case are also present in the case at

180 See Eisenberg, The Nature of the Common Law at 154 (cited in note 13) ("Doctrinal propositions adopted in past texts are a fundamental starting point in determining the content of the common law, but they do not comprise the content of the common law. What then does the common law consist of? It consists of the rules that would be generated at the present moment by application of the institutional principles of adjudication.").

${ }^{181}$ See Edward H. Levi, An Introduction to Legal Reasoning 2-3 (Chicago, 1948) ("It is not what the prior judge intended that is of any importance; rather it is what the present judge, attempting to see the law as a fairly consistent whole, thinks should be the determining classification."); Steven J. Burton, An Introduction to Law and Legal Reasoning 36-37 (Little, Brown, 1985); Frederick Schauer, Precedent, 39 Stan L Rev 571, 580-81 (1987); Alexander, $63 \mathrm{~S} \mathrm{Cal} \mathrm{L} \mathrm{Rev} \mathrm{at} \mathrm{28-34} \mathrm{(cited} \mathrm{in} \mathrm{note} \mathrm{176)} \mathrm{(conceding} \mathrm{that} \mathrm{this} \mathrm{is} \mathrm{the}$ most familiar and widely accepted account of precedent, but contending that it is incoherent); Ruggero J. Aldisert, Precedent: What It Is and What It Isn't; When Do We Kiss It and When do We Kill It? 17 Pepperdine L Rev 605, 607 (1990).

This understanding of precedent is quite ancient, but has long coexisted uneasily with the positive law view. See F.T. Plucknett, A Concise History of the Common Law 347 (Little, Brown, 5th ed 1956) ("In the Year Book period [circa 1300-1500] cases are used only as evidence of the existence of a custom of the court. It is the custom which governs the decision, not the case or cases cited as proof of the custom . . . . A single case was not a binding authority, but a well-established custom (proved by a more or less casual citing of cases) was undoubtedly regarded as strongly persuasive.").

For a now classic debate on the extent to which a court's statements of the rule or of the facts control subsequent courts, see J.L. Montrose, Ratio Decidendi and the House of Lords, 20 Mod L Rev 124 (1957); A.W.B. Simpson, The Ratio Decidendi of a Case, 20 Mod L Rev 413 (1957); J.L. Montrose, The Ratio Decidendi of a Case, 20 Mod L Rev 587 (1957); A.W.B. Simpson, The Ratio Decidendi of a Case, 21 Mod L Rev 155 (1958); A.L. Goodhart, The Ratio Decidendi of a Case, 22 Mod L Rev 117 (1959); A.W.B. Simpson, The Ratio Decidendi of a Case, 22 Mod L Rev 453 (1959); Julius Stone, The Ratio of the Ratio Decidendi, 22 Mod L Rev 597 (1959). 
bar. If so, the judge should reach the same result as in the prior case, unless she finds other "important" facts that would distinguish the case at bar. Although later judges, in evaluating factual similarities to a prior precedent, may consider only the facts mentioned in the prior court's opinion, ${ }^{182}$ they are free to redescribe, recategorize, and reevaluate those facts and thereby to move beyond the rule announced in the prior case. ${ }^{183}$

From the positive law perspective, this is baffling. How can a lower court pick out a material fact that should make a difference in the application of a rule if the judge knows only the law articulated by the lawgiver? How does a judge decide when to depart from the rule as articulated?

The common law view of precedent can be better understood in light of the way language works. Like knowing a language, knowing the law presupposes a great deal of background knowledge of a cultural way of life, knowledge that cannot be fully captured by deductive reasoning from articulated rules. At some level, Blackstone was right: judges seem already to know the law

: 182 See Simpson, 21 Mod L Rev at 160 (pointing out that accepting a prior judge's determination of which facts are material is tantamount to following the announced rule, not just the result).

${ }_{183}$ See, for example, Cohens $v$ Virginia, 19 US (6 Wheat) 264, 399-401 (1821):

It is a maxim not to be disregarded that general expressions, in every opinion, are to be taken in connection with the case in which those expressions are used .... The reason of this maxim is obvious. The question actually before the Court is investigated with care, and considered in its full extent. Other principles which may serve to illustrate it, are considered in their relation to the case decided, but their possible bearing on all other cases is seldom completely investigated.

...

... Having such cases only in its view, the [Marbury Court] lays down a principle which is generally correct, in terms much broader than the decision, and not only much broader than the reasoning with which that decision is supported, but in some instances contradictory to its principle.

See also Michael S. Moore, Precedent, Induction, and Ethical Generalization, in Laurence Goldstein, ed, Precedent in Law 183, 185 (Oxford, 1987):

Subsequent courts feel bound by the level of generality in description of the facts of the prior court, or of which of such facts (at any level of description) is material to the decision, no more than they feel bound by the statement of holding; subsequent courts likewise feel free to disregard the stated justificatory reasons given by the deciding judge whenever the later judges can discern for themselves a better rationale for the older decisions than was apparent to those who made them.

See also Eisenberg, The Nature of the Common Law at 66-68 (cited in note 13) ("An announced rule that fully satisfies the standards of social congruence and systemic consistency should be reformulated when a case arises that falls within the stated ambit of the rule, but that requires different treatment given the social propositions that support the rule .. . "); Frederick Schauer, Is the Common Law Law? 77 Cal L Rev 455, 464 (1989) ("[C]ommon law adjudication is a process that allows judges to remake the existing doctrinal propositions in the process of applying them."). 
before they articulate it. As others have pointed out, grouping cases as similar or different, which is the essence of common law reasoning, is not a simple matter of applying preestablished categories to sets of facts. The categories themselves are not tidy or static. Instead, the intuition of similarity or difference is in part dependent on the background customs or "forms of life" of a linguistic community. ${ }^{184}$ This interweaving of law with custom is, in an important sense, natural law. ${ }^{185}$

184 See Schauer, 39 Stan L Rev at 585-86 (cited in note 181) ("[D]ecisionmaking within the legal structure is constrained by the comparative fixity of those larger societal and linguistic categories that help to constitute the conceptual apparatus of lawyers and judges."); Burton, Law and Legal Reasoning at 91-99 (cited in note 181); Cass Sunstein, On Analogical Reasoning, 106 Harv L Rev 741, 755 \& n 53 (1993). All three writers draw on Ludwig Wittgenstein, G.E.M. Anscombe trans, Philosophical Investigations (Macmillan, 3d ed 1969). For examples of cultural differences, see Dorothy Lee, Symbolization and Value, in Dorothy Lee, Freedom and Culture 78, 80-88 (Spectrum, 1959) (pointing out that the categories of other cultures are very different); Walter Ong, Orality and Literacy: The Technologizing of the Word 78-116 (Methuen, 1982) (illustrating how literacy changes the conceptualization of the world). See also Michael Devitt and Kim Sterelny, Language \& Reality: An Introduction to the Philosophy of Language 172-184 (MIT, 1987).

185 One fine contemporary attempt to connect natural law and common law adjudication is by Professor Michael Moore. See generally Michael S. Moore, A Natural Law Theory of Interpretation, $58 \mathrm{~S}$ Cal L Rev 277 (1985). According to Moore, words refer to some natural distinction out in the world that we have yet fully to discover or to understand (word meaning is "indexical"). There is a reality; word meaning is not "just" manipulable human convention or nominalism. Yet, he claims, our epistemology may be coherentist, even if our ontology is realist-we may have no better way to seek the truth than to seek the most coherent theory of it. Common law adjudication, in its search for coherence, may be the only way we can approach the truth.

While I am in sympathy with Moore's anti-skeptical project, his vision of the thingin-itself toward which we strive, never to know whether we have gotten there or not, is itself nihilistic. It is nihilistic in the sense that it assumes we never get to truth, nor even know whether we are getting closer. There is no guarantee that our "best" theory is closer to the truth than some other theory; it is just more coherent. In short, no link exists between the coherentist epistemology and the realist metaphysics. Our epistemology is a Sisyphean futility. As a result, Moore's realism easily slides into "mere" conventionalism-since we never get to the real truth, any practice we choose will be equally as good or bad as any other; we can choose any one we want.

I would rather say that there is no further reality with which to compare our world. Our ways of reasoning (which emphasize coherence) tell it like it is. At bottom, the difference is in how we conceive of the world around us. If it is only an object or manifold of objects (self-contained, separate from us), then we never really know it (as it is in itself apart from us). If reality is instead permeable to our understanding (not self-contained, not separate from us), then we can and do already know it.

Not incidentally, the idea of a natural law in which truth is "immanent" may be more faithful to the origins of common law than the natural rights theory of the Enlightenment, which posits truth outside history in a theoretical state of nature. See Pocock, Ancient Constitution at 30-41, 233-37 (cited in note 12) (Locke's natural rights theory occurs only after the idea of immemorial custom has been reinterpreted as the immemorial sovereignty of parliament-turned into positive law.). See also Trisha Olson, The History of English Punishment: From Redemption to Reform 14 (unpublished paper on file with U Chi L Rev) ("Aware of its limits, the medieval mind modestly refrains from seek- 


\section{The temporal aspect of common law.}

The customs of natural language that inform law employ generalizations that overlap and grow organically, not mechanically. They originate in habits, actions taken over long periods of time, and patterns of particular judgments. ${ }^{186}$ Because the meanings of words in natural languages develop from use in particular situations rather than from a priori definitions, words are not univocal; rather, their sense grows with the accretions of meaning acquired in different contexts. ${ }^{187}$ This organic growth of language is not a deficiency, but rather is necessary to our understanding the world. Language relies on analogy and metaphor to connect the unfamiliar to the familiar; if it did not, each new situation would render us speechless. ${ }^{188}$ Deductive reason, by contrast, can only organize or reorganize; it cannot assimilate. ${ }^{189}$

Common law adjudication operates in much the same way as natural language. Just as words accrue meaning through use, common law reasoning seeks to connect one situation to another through analogies. Analogy connects the unfamiliar with the familiar by connecting a particular, random event (in the present) with other events (in the past). ${ }^{190}$ The common law thus

ing the unconditional truth of the matter. On the other hand, the medieval mind has faith that the world it inhabits illuminates some portion of the truth.").

${ }^{186}$ See Wittgenstein, Philosophical Investigations at $\S \S 43,54,146,241-42,337$ (cited in note 184) (claiming abstractions, rules, principles, even definitions of words, are generalizations from a practice of habitual judgments); Martin Heidegger, John Macquarrie and Edward Robinson trans, Being and Time 95-97, 114-17 (Harper \& Row, 1962) (generalizations and categorization are based on and derived from everyday habits and practices-speaking of "hammers" or "tools" is only possible on the basis of having experienced their use and their practical connections with other things in the world). Compare Blackstone's definition of a good custom, which requires that it be a practice "used so long, that the memory of man runneth not to the contrary." Blackstone, 1 Commentaries at *76.

${ }_{187}$ Wittgenstein's familiar discussion of family resemblance makes this point. See Wittgenstein, Philosophical Investigations at $\$ \$ 66-76$. Consider also the Oxford English Dictionary's approach to definition by examining usage through time.

188 See Schauer, Playing by the Rules at 34-37, 41 (cited in note 172).

189 See Sunstein, $106 \mathrm{Harv} L$ Rev at 782 (cited in note 184) ("[A]nalogical reasoning has the important advantage of allowing a large degree of openness to new facts and perspectives."). Compare Eisenberg, The Nature of the Common Law at 159 (cited in note 13) (if law were purely deductive, courts would be unable to determine whether claimants with novel claims are entitled to relief).

${ }^{190}$ See Heidegger, Being and Time at 411 (cited in note 186) ("The as-structure is grounded ontologically in the temporality of understanding."). The comparison involved in analogizing is not a counting up of two objects' similar characteristics. See Eisenberg, The Nature of the Common Law at 83-84 (cited in note 13). Instead, the context and point of the comparison will determine which characteristics are particularly salient. In fact, the setting of the case under decision may tend to bring to the fore characteristics in older 
always connects the present with the past. ${ }^{191}$ This connection with the past makes sense of the present case by seeing it as part of a whole and thereby lending it continuity and direction into the future. As a connection between past and future, between this situation and others, common law can never be "new" without being senseless. Law is the bridge between new and old. Law, by its analogical nature, will always rely on what already is to make sense of what is new. ${ }^{192}$ Hence, the distinction of new and old rules is neither clear nor appropriate from the perspective of common law adjudication. ${ }^{193}$ A "new" rule is an illegitimate one, a senseless one. ${ }^{194}$

cases that did not stand out before.

${ }^{191}$ Frederick Schauer would not attribute this backward-looking aspect to common law reasoning, since it does not require absolute adherence to previously established rules. Instead, he characterizes common law reasoning as focused on doing the right thing now. Schauer, Playing by the Rules at 173-81 (cited in note 172). His view that rule-bound decision making is more faithful to the past than contextual decision making may be open to question, however. Often very radical departures from past practice may be obtained by formalistic interpretations of old rules. Contrast Caminetti v United States, 242 US 470 (1917) (White Slave Traffic Act, 36 Stat 825 (1910), determined not to include a pecuniary gain requirement, thus applicable to simple adultery), with Church of the Holy Trinity $v$ United States, 143 US 457, 459 (1892) (refusing to apply a statute forbidding corporations from importing alien workers to a case involving a church that hired its minister from overseas because, though within the letter, not within the spirit of the statute). See also Wittgenstein, Philosophical Investigations at $\S 70$ (cited in note 184) ("Someone says to me: 'Shew the children a game.' I teach them gaming with dice, and the other says, ' didn't mean that sort of game.").

${ }^{192}$ Ken Kress has argued that coherence theories of law necessarily involve some unfair retroactivity. Kenneth J. Kress, Legal Reasoning and Coherence Theories: Dworkin's Rights Thesis, Retroactivity, and the Linear Order of Decisions, $72 \mathrm{Cal} \mathrm{L}$ Rev $369,380-402$ (1984). Because each new decision becomes a new strand in the preexisting fabric of law against which subsequent decisions are measured, decisions rendered during the time between the events giving rise to litigation and the time of judicial resolution change the law after the fact. Applying later decisions to events occurring before they were decided is unfair. Kress's theory might be illustrated by the Edwards, Roberson, Butler line of cases. Although Roberson followed from Edwards, according to Butler it was a new rule, because it "enacted" the irrelevance of the distinction that would have been reasonable prior to Roberson. As Kress recognizes, his theory only works if decisions have "positive law" effects, or if the considerations guiding those decisions were not contemporaneously available. A common law version of precedent does not satisfy either condition. Precedent has no static meaning. Holdings are open for reinterpretation, and no body of rules is ever "enacted." Moreover, the ability to make distinctions assumes that the relevant considerations are already available. There is no unfair surprise; there is only "unreasonableness." Retroactivity is, in some sense, a non-issue for common law.

193 See Sunstein, 106 Harv L Rev at 774 (cited in note 184).

194 These thoughts are very loosely based on Martin Heidegger's account of time in Being and Time (cited in note 186). Heidegger might go farther, however, and note that the positive law account of time as a sequence of points or the change (movement) of physical objects (words on paper) is an abstracted and derivative account of time that does not fit with the true nature of what is. See id at 464-77 (Time as a "sequence of nows" or movement of a pointer is an abstraction from our experience and reflects a misleading 
Because language grows from context, it makes sense for the judgment taken in context, rather than the judge's reasoning or enunciated rule, to be authoritative. The same process is reenacted in law school Socratic discussions, in which grand statements of principle are honed and sharpened by demonstrations that they lead to "absurd" results; students study cases, not treatises. Indeed, many jurists report that, after reading many cases, the sense of the right result in the case under decision is clearer than the "principle" that would capture the continuity. ${ }^{195}$ Having looked at a series of examples, one intuitively knows "how to go on in the same way" without necessarily being able to state the rule. ${ }^{196}$ In short, the common law assumes that our ability to

vision of "ultimate reality" as segmented, monad-like, and infinite.). Common law preserves an account of time more closely related to our world: respect for the past is tantamount to respect for significance, because we learn and know only by projecting our past understanding into the future, that is, by analogizing the new to the familiar. Time is not a progression of discrete moments, but the realm within which things take on significance, have meaning and direction. See id at 466-67. A similar view is expressed in Anthony T. Kronman, Precedent and Tradition, 99 Yale L J 1029, 1064-68 (1990) (Following precedent need not be justified in a utilitarian way by equality, stability, or reliance concerns, but is instead good for its own sake, as respect for an inheritance of meaning.).

195 See Oliver W. Holmes, Jr., Codes, and the Arrangements of the Law, $5 \mathrm{Am} \mathrm{L} \mathrm{Rev} 1$ (1870), reprinted at 44 Harv L Rev 725, 725 (1931) ("It is the merit of the common law that it decides the case first and determines the principle afterwards."); Joseph C. Hutcheson, Jr., The Judgement Intuitive: The Function of the "Hunch" in Judicial Decision, 14 Cornell L Q 274, 278 (1929) ("I, after canvassing all the available material at my command, ... give my imagination play, and brooding over the cause, wait for the feeling, the hunch-that intuitive flash of understanding which makes the jump-spark connection between question and decision...."). See also Sunstein, 106 Harv L Rev at 746 ("Ideas are developed from the details, rather than imposed on them from above. In this sense, analogical reasoning, unlike many forms of reasoning, is a version of 'bottom-up' thinking."). See also Ken Kress, Legal Indeterminacy, 77 Cal L Rev 283, 334 (1989):

We should accept the richness and complexity of the moral decisionmaking and interpretive methods which inform law. We may not be able to deduce legal outcomes in advance, but nonetheless we have a rational, nonarbitrary process by which we can implement the abstract demands of justice.

...

.. Resolving conflicting principles in concrete settings or deciding cases of first impression requires judgment which may be more akin to art than to science.

See also Charles M. Yablon, Justifying the Judge's Hunch: An Essay on Discretion, 41 Hastings L J 231, 261-68 (1990) (portraying judging as a skill, not reducible to articulated rules).

196 This approach is different from the extreme legal realist or critical legal studies position that decisions in cases result from the personal views or quirks of the judges, not from the law. Compare Schauer, Playing by the Rules at 191-96 (cited in note 172). One may recognize that judges do not proceed primarily by weighing and interpreting different rule formulations without being forced to the skeptical conclusion that judges merely pursue their peculiar interests, politics, or visions. To avoid the Hobson's choice between skepticism and some kind of formalist explanation of judging, one has to accept the possibility that knowledge gained through analysis of particular cases may not be immediately 
sense the continuation of a pattern in a particular context will be keener than our ability to explicate a rule.

Although law is dependent on these situational intuitions, we should not skeptically conclude that it is therefore subjective or "result-oriented" in a narrow, selfish way. ${ }^{197}$ We share these intuitions with others within our practice. From this standpoint, law is no more subjective than language, whose structure itself requires that law be tied to context. And language works pretty well: most of the time, we understand each other. ${ }^{198}$

Nor is this dependence on history a crass brand of conventionalism or conservatism. History is not dogma. Our relation with the past should be that of a student, not a mortician. ${ }^{199}$ History is the contextual experience and knowledge that provides us with any understanding at all; it cannot be compared with some other way of knowing, because there is no other way. We humans cannot rise above our world of custom to discern some other pure reason; we weave our future with the many, varied strands of our past. ${ }^{200}$

translatable into fully articulated rules, and that following examples may come more easily for us than rule theorists acknowledge. This approach may not be so far-fetched, especially since much of our early learning as children is by example, not by rule-based deduction. Consider Steven L. Winter, Transcendental Nonsense, Metaphoric Reasoning, and the Cognitive Stakes for Law, 137 U Pa L Rev 1105, 1156-59 (1989) (arguing that "categorization" is itself based on a metaphor-but metaphoric reasoning should not be thought as leading to subjectivism, as we humans share common cognitive capacities and therefore common metaphors).

197 The temporal and cultural contingency of the rules of life and language is not controversial. But it does not follow from the temporal and cultural contingency of rules of relevance that they are subject to change by a given decisionmaker, or even by a particular decisionmaking institution. That a society may change its collective views about what counts as a "vehicle," or what is "liberal," "fair notice," or "cruel," does not mean that the power to accomplish any of these changes exists in the short run, or inheres in individual or institutional decisionmakers.

Schauer, 39 Stan L Rev at 585 (cited in note 181).

198 Compare Winter, $137 \mathrm{U}$ Pa L Rev at 1110-11 ("Part of what is troubling about the subjectivist approach to law is that it assumes that we have more trouble communicating than we actually do.").

199 See Rebecca L. Brown, Tradition and Insight, 103 Yale L J 177, 180 (1993) (Adherence to history in constitutional adjudication should not be a responsibility-abjuring retreat to authority, but an endeavor to garner understanding from "the wisdom and experiences of prior generations.").

${ }^{200}$ Custom, here, should not be understood as a "fact" about behavior, but from the "internal point of view" as normative guidance. See Hart, The Concept of Law at 87-88 (cited in note 173). At its deepest level, custom is the rock-bottom evaluation of the world that enables us to think at all. If we criticize "custom," at some level we do so only from the standpoint of another "custom." No further "value-free" description or explanation can be given, because every explanation would assume that we could stand outside of it and evaluate it in terms of something else. See Moore, Precedent, Induction, and Ethical Generalization at 198-200 (cited in note 183) (Conventionalism assumes we can stand 


\section{The distinction with a difference.}

In addition to allowing historical growth, the contextuality of language permits any particular to be described in thousands of ways, pointing out this or that relation to other things in the (past) world. The description that language-and by extension, law-will give to an action or thing will depend upon which aspect of it is important to human action at the moment. My grandmother's old oak rocker is a rocker (when I need to distinguish it from an easy chair), a chair (when I need to tell the movers what I have), a wooden object (when I am concerned about fire damage), a medium brown with a bit of green (when I am redecorating), furniture (when classifying it for insurance purposes), a moveable (when I want to distinguish my property from my landlord's), a chattel (when I want to discuss ownership), a lulling motion (when I want to get my child to sleep), an antique (when I think about its value on the market), an heirloom (when I think about its family history), a thing of beauty (when I look up from my computer to watch the light play upon it), and so forth. Each description relates it to human action; ${ }^{201}$ which is relevant or important or "material" depends on the context or the purpose of the action. ${ }^{202}$ By extension, a fact in a case has analogical importance not intrinsically, but by reference to the point of the inquiry. The common law, by keeping the focus on the context, sees that the statement of any rule is always tied to the point to which we are attending. ${ }^{203}$

outside convention and see that it is contingent, "mere" convention. Realism is, ironically, humbler.).

${ }^{201}$ See Schauer, Playing by the Rules at 18-20 (cited in note 172) (explaining that "discursive context" determines what features of a situation we emphasize in describing it).

${ }^{202}$ Heidegger, Being and Time at 114-18 (cited in note 186). The example in the text is somewhat misleading. The human "purpose" behind description is not purpose in the sense of a personal, selfish desire; obviously the meanings of words do not change at my whim. See Schauer, Playing by the Rules at 215-21. Rather, "purpose" refers to the human world of action in which we together reside. We do things. Our lives are not aimless, so neither is the language we have. Language draws manifold distinctions among things because we (our linguistic culture) need to make those distinctions. We Southerners don't need to distinguish between umpteen different kinds of snow; Inuits do. Words make the distinctions that are important to us, thus, their meaning is often closely tied to the purpose of human action in a context. See Fuller, 71 Harv L Rev at 664-66 (cited in note 178). Purposes are, in this broader sense, part of the meaning of words. This objection to determining meaning by reference to purpose usually assumes that purposes are private, contingent products of individual wills and thus cannot be the ground for public meanings. The objection ignores that even the range of our "personal" purposes is governed by our culture.

${ }^{203}$ See Sunstein, 106 Harv L Rev at 775-81 (cited in note 184). Some writers suggest that these purposes or principles in the background can be stated as second-order rules. 
Some descriptions are tied to customs within the legal community, rather than the linguistic community as a whole. Flagburning and the wearing of black armbands are "similar" given the background of First Amendment case law; ${ }^{204}$ a drunken act and an angry act may be "similar" within the tradition of criminal law. Although knowledge of legal distinctions requires special legal knowledge and experience, ${ }^{205}$ common law reasoning presupposes that the "importance" of facts is already available to the judge, just as the "importance" of facts in everyday description is already available to the competent user of a natural language. The judge is not just reading prior statements of other judges; she is supposed to know already what sorts of facts might be important in particular contexts. ${ }^{206}$ Thus, judges are not limited to adopting distinctions made by prior cases, but may point to spe-

See Schauer, Playing by the Rules at $50 \mathrm{n} 15$ (cited in note 172). It is not clear that this is true, since any attempt to articulate these principles would, like the first-order rules, be over- and under-inclusive, requiring third-order rules to amend them, and so on ad infinitum. In the end, workable institutions are based on compromises among these goals worked out through time. See Kronman, 99 Yale L' J at 1055-57 (cited in note 194); Edmund Burke, Reflections on the Revolution in France 193-94 (Conor Cruise O'Brien, ed) (Penguin, 1969). See also Blackstone, 1 Commentaries at *70:

Not that the particular reason of every rule in the law can at this distance of time be always precisely assigned; but it is sufficient that there be nothing in the rule flatly contradictory to reason, and then the law will presume it to be well founded. And it hath been an ancient observation in the laws of England, that whenever a standing rule of law, of which the reason perhaps could not be remembered or discerned, hath been wantonly broken in upon by statutes or new resolutions, the wisdom of the rule hath in the end appeared from the inconveniences that have followed the innovation.

204 See Texas $v$ Johnson, 491 US 397 (1989); Tinker v Des Moines School Dist., 393 US 503 (1969); Sunstein, 106 Harv L Rev at 769-73.

${ }^{205}$ See Blackstone, 1 Commentaries at *69 ("[Judges'] knowledge of that law is derived from experience and study; from the 'viginti annorum lucubrationes' (the lucubrations of twenty years), which Fortescue mentions; and from being long personally accustomed to the judicial decisions of their predecessors."). See also Hale, The Common Law of England at 45 (cited in note 12):

Tho' judiciall Decisions are less than a Law [which only the King or Parliament can make], yet they are a greater Evidence thereof than the Opinion of any private Persons....

[First, b]ecause the Persons who Pronounce those Decisions, are Men chosen by the King for that Employment, as being of greater Learning, Knowledge, and Experience in the Laws than others. [Second, blecause they are upon their Oaths to judge according to the Laws of the Kingdom. [Third, b]ecause they have the best Helps to inform their Judgments. [Fourth, b]ecause they do Sedere pro Tribunali, and their Judgments are strengthen'd and upheld by the Laws of this Kingdom, till they are by the same Law revers'd or avoided.

206 See Hale, The Common Law of England at 46 (listing among the kinds of judicial decisions those that (1) "have their reasons singly in the Laws and Customs of this Kingdom," (2) those that "by Way of Deduction and Mlation upon those Laws are framed or deduced," and (3) those that "have no other Guide but the common Reason of the Thing"). 
cial facts in the case at bar that are significant even though never before mentioned. For example, the fact that a woman accused of murdering her husband had been subject to a history of abuse may be considered relevant, even if no prior case had alluded to this fact. ${ }^{207}$

The converse also holds: the mere existence of a distinction in one case does not qualify it as a reasonable distinction in another. The fact that acceptance is required for a contract does not mean that a defendant in a tort suit can claim that the plaintiff's lack of "acceptance" justifies a dismissal. Likewise, although race is a relevant distinction in affirmative action cases, it is not relevant in criminal cases.

The significance of the assumed and unspoken in the law sometimes appears vividly in legal papers drafted by untrained pro se litigants. Unrepresented parties often comb the digests for rules or statements of law that they then apply indiscriminately to their own cases, relying on the perception (fostered by the legal profession) that law is a deductive science. The resulting legal arguments seem to come from a different planet-but the seasoned legal observer may be at a loss to explain to the novice why, for example, the racial animus of a court reporter doesn't amount to trial "prejudice," or why a prosecutor's guidelines for plea bargaining are not "price-fixing."

In short, the common law approach assumes the law is already there to be discovered. On the basis of common sense (natural linguistic intuitions, "reason," or "situation sense"209) and

207 See, for example, People v Torres, 48 NYS2d 358, 128 Misc 2d 129 (NY S Ct 1985) (allowing, for the first time in New York, "battered woman syndrome" evidence as part of the defendant's justification defense).

${ }^{203}$ Another example appeared in a comic advice column in the Vanderbilt Law School student newspaper:

Dear Learned Hand:

I am very attracted to my next-door neighbor. Trouble is, he is just 17 years old. Having just completed [a] criminal law course, I know acting on my impulses will get me in trouble. Any advice?

-Frustrated in Franklin

Dear Frustrated:

A legal analysis of your plight is in order. Your affections for your neighbor, assuming arguendo that they are reasonable and of "substantial intensity," create a legally cognizable property interest. The state, in the form of statutory rape laws, has prevented the two of you from realizing the full use of that property interest. This looks strikingly similar to a Lucas $v$. Coastal Carolina [sic] taking. Your only recourse is to commence litigation in order to receive reasonable compensation.

Ask Learned Hand: Advice to the lovelorn, 10 The VLS Brief 6 (Oct 1993) (on file with U Chi L Rev).

${ }^{209}$ See Karl N. Llewellyn, The Common Law Tradition: Deciding Appeals 60-61 
general legal knowledge, the judge can find material distinctions and refuse to follow a rule articulated in a prior case even if the case at bar is within the language of the "rule" of a case as expressed by the prior court.

If common law judges recognize the "importance" of various factual distinctions, they can hardly be surprised by a decision based on an analogy from prior cases. Common law does not spring out of the lawmaker's head, but is deliberately stalked, analogy by analogy, metaphor by metaphor, case by case. Judges must be considered part of the community within which the "importance" of facts is salient. Some indeterminacy, leeway, or reasonable disagreement is part of the territory, but the disagreement takes place within the boundaries of already accessible considerations. ${ }^{210}$ Judges can and do anticipate the reasonable range of "material" considerations. ${ }^{211}$ Hence, their reliance on a rule as announced in a prior case is not reasonable reliance if there are material factual differences between the cases. ${ }^{212}$ Correlatively, any truly "new" rule is an incomprehensible one.

In sum, positive law and common law are fundamentally incompatible. Positive law theory views law as a set of statements of rules by an authority, whereas common law theory views law as a set of patterns for human action that cannot be reduced to fixed statements. This basic distinction leads to different understandings of precedent. The positive law conceives precedent as previously announced general rules from which judges can deduce applications. If no deduction is possible, then a judge creates a new rule. The common law conceives precedent as previously resolved controversies that can be used as analogies to

(Little, Brown, 1960).

${ }^{210}$ Compare Paul J. Mishkin, Foreword: The High Court, The Great Writ, and the Due Process of Time and Law, 79 Harv L Rev 56, 60 (1965):

Actually, while the Blackstonian conception is not entirely valid, neither is it wholly wrong. For it is certainly true that courts in general handle the vast bulk of cases by application of preexisting law; indeed, even when "new law" must be made, it is often in fact a matter of the court articulating particular clear implications of values so generally shared in the society that the process might well be characterized as declaring a preexisting law. Moreover, this must inevitably be so. For it is the basic role of courts to decide disputes after they have arisen. That function requires that judicial decisions operate (at least ordinarily) with retroactive effect. In turn, unless those decisions (at least ordinarily) refiect preexisting rules or values, such retroactivity would be intolerable.

211 See, for example, Taylor $v$ Gilmore, 954 F2d 441, 453 (7th Cir 1992) (anticipating the distinction later drawn by the Supreme Court in the same case).

${ }_{212}$ Compare Stephen R. Munzer, A Theory of Retroactive Legislation, 61 Tex L Rev 425,431 (1982) (arguing that an element of rational expectations is "some ability to replicate the expectations and reasoning of others"). 
guide future judgments. A judge blends old and new to reach her decisions-the current controversy sheds light on past cases and vice versa. Prior judgments do not logically entail present ones, but no judgment is completely discontinuous with precedent (unless it is wrong). The precedential force of prior cases comes not from the statements of the judges, but from the good sense of their judgments. The "holding" of the case is therefore that good sense, and not what is said (which is mere dicta).

\section{ThE TROUBLE -WITH TEAGUE}

The trouble with Teague is that the Court tries to equate the distinction between new and old rules with the distinction between dicta and holding. But the new/old rules distinction makes sense only from a positive law standpoint, while the dicta/holding distinction makes sense only from a common law standpoint. By equating the two, the Court blurs both distinctions, which in turn threatens to reduce the Court's adjudication to sophistry. By defining "new" as "not dictated by precedent," the Court implies that "new" law surprises state courts, and it downplays the continuity of analogical reasoning. On the other hand, the Court's use of a common law form of precedent does not require that state courts adhere to the articulated positive law rules in the Court's prior opinions, either. Instead, state courts can freely distinguish and redescribe the Court's holdings. Even cases that fall within the ambit of an articulated rule are not "dictated" by precedent.

If the Court is really concerned with protecting reasonable reliance on prior law, it could avoid the problems Teague poses by accepting limits on reasonable reliance imposed by either the positive law or common law. The following Sections discuss what those limits might look like.

\section{A. Reasonable Reliance on Positive Law}

If law is unknowable until articulated, it should at least be knowable if articulated. The logical place for lower courts to look for guidance is the rule as articulated by the Supreme Court itself. The Court, however, has held that the statement of the rule in a prior case is not necessarily binding. ${ }^{213}$ In Butler, the Court declined to hold state and lower courts to the rule as artic-

${ }^{213}$ See Butler v McKellar, 494 US 407 (1990); Saffle v Parks, 494 US 484 (1990); Graham v Collins, 113 S Ct 892 (1993). 
ulated in Edwards, but instead allowed them to distinguish the case on its facts. ${ }^{214}$ Likewise, in Parks and Graham, the Court set aside language in Penry, Lockett, and Eddings and held that the prior case law could be reasonably interpreted to allow for an exception to the rule as stated. ${ }^{215}$

Ironically, the Court has reached this conclusion by recognizing that state courts can tell when it is appropriate to craft exceptions to a rule articulated in a precedent. That is, state courts can discern the law without the benefit of a prior statement of the rule. At the same time, however, the Court asserts that its own use of analogical reasoning unfairly surprises state courts. The Court is having it both ways.

Should the Court wish to continue this "new rule" jurisprudence, it could adopt a positive law approach, under which the rules stated in a prior case would determine present controversies. For example, the Roberson Court held itself to be governed by $E d w a r d$ 's statement that police must stop questioning a suspect who has asked for an attorney. Using a positive law account of precedent, the statement in Edwards dictated the result in Roberson, because $E d w a r d s$ did not explicitly add an exception for interrogations concerning a different crime.

Taking the language of prior cases literally would give the Court control over retroactivity, allowing it to vary the precedential value of its cases by varying the level of generality at which it states its holdings. ${ }^{216}$ For example, the Court might sometimes state its holdings in very fact-specific terms, so that they would govern in fewer cases. Or, it might state a holding in broad terms that would govern many cases. Of course, this would also require the Court to predict the future-to take into account the future impact of its precise language in formulating rules. ${ }^{217}$

Justice Kennedy advocated a similar approach in Wright $v$ West. ${ }^{218}$ There, he contrasted rules formulated by the Court that "of necessity require[ ] a case-by-case examination of the evidence" with those that are not so context-dependent. ${ }^{219}$ For example, a rule requiring that evidence of guilt be "sufficient" can be applied in many different factual contexts without creating

214 See text accompanying notes 65-77.

${ }^{215}$ See text accompanying notes $83-89,117-22$.

216 See Wright $v$ West, 112 S Ct 2482, 2499 (1992) (Kennedy concurring).

${ }_{217}$ See Scalia, 56 U Chi L Rev at 1178-85 (cited in note 176) (contending that judges should articulate clear, general, and predictable rules of law).

218112 S Ct 2482.

219 Id at 2499 (Kennedy concurring). 
new law: "Where the beginning point is a rule of this general application, a rule designed for the specific purpose of evaluating a myriad of factual contexts, it will be the infrequent case that yields a result so novel that it forges a new rule, one not dictated by precedent."220 Kennedy's view in West, consistent with a positive law approach, looks to the level of generality at which a rule is stated in a prior case.

\section{B. Reasonable Reliance on Common Law}

In a system of analogical reasoning, reliance is not tied to adherence to a stated rule. Judges are assumed to know the general range of arguments, which facts are significant, and the purposes that guide the rules. The law is, in large part, already there, even though the result of a particular case is never preordained. Each situation will be different from those that have come before; the challenge is to characterize new situations in ways that make their links to the past clear and sensible. Because the relevant considerations are available to all judges or lawyers with access to the same cultural and legal materials, in most cases there is no element of unfair surprise. ${ }^{221}$ And without unfair surprise, retroactive application of law is justified.

The Court has generally followed this approach in its tax refund cases, in which Blackstone makes a return after his banishment in Linkletter. ${ }^{222}$ As mentioned above, the Court had initially applied Linkletter-type analyses in cases outside the criminal law context in Cheuron Oil Co. ${ }^{223}$ Later, after the Court abandoned Linkletter in the criminal law context, it also moved to abandon it in the civil law context. ${ }^{224}$

In the Teague cases, however, the Court has taken a different view of reasonable reliance. In Sawyer, for example, the background law in the states established quite clearly that a prosecutor should not mislead a jury about its responsibilities. ${ }^{225}$ While no Supreme Court case had addressed precisely these facts, the litigants sought to draw on analogies that were available in relat-

220 Id.

${ }^{221}$ The assumption that we share a common culture is a very large assumption, but one that undergirds the common law. Indeed, for the common law, culture is law.

222 Linkletter $v$ Walker, 381 US 618 (1965). See James B. Beam Distilling Co. $v$ Georgia, 111 S Ct 2439, 2443-48 (1991); id at 2451 (Scalia concurring); Henry Harper v Virginia Dep't of Taxation, $113 \mathrm{~S} \mathrm{Ct} 2510,2520-24$ (1993) (Scalia concurring).

${ }_{223}$ Chevron Oil Co. $v$ Huson, 404 US 97 (1971).

${ }^{224}$ See note 42.

${ }_{225}$ Sawyer v Smith, 497 US 227 (1990). See text accompanying notes 90-97. 
ed cases. Nonetheless, the Court held that the state courts reasonably relied on the lack of prior federal case law on point. ${ }^{226}$ Thus, in Sawyer the Court took a positive law view, requiring that the rule be explicitly stated in a prior case from the proper legal source.

\section{Which Paradigm Should Control?}

The choice, then, is between a positive law approach that allows reasonable reliance on articulated rules, and a common law system that relies on analogical reasoning. Most of the time, state courts should and do treat Supreme Court opinions as products of the common law system.

Professor Schauer's analysis of rule-based decision making sheds considerable light on when relying on rules is reasonable. ${ }^{27}$ First, he explains that the possibility of formulating positive law rules arises when certain categorizations become entrenched through continued use. Words, even out of context, come to stand for a fairly stable set of characteristics (or "universal context") ${ }^{228}$-suppressing other characteristics as irrelevant. ${ }^{229}$ When these entrenched generalizations are used in formulating rules, the rules can be applied outside their original context. ${ }^{230}$

Schauer demonstrates that applying rules using these entrenched categories cuts off a decision maker's ability to discern some of the relevant decision-making factors, resulting in suboptimal decisions. ${ }^{231}$ In other words, we fail to notice facts that should make a difference, applying a rule in a case when it should not be applied because the application would defeat the purposes of the rule itself, or because other considerations should trump the rule.

Schauer argues that rule-based decision making is nonetheless useful for decision makers who (1) have little time to take

226 Sawyer, 497 US at 235-36.

${ }_{227}$ Schauer, Playing by the Rules (cited in note 172).

228 Id at 57.

229 Id at 42-47 (generalizations become entrenched, cutting off our perception of the differences they mask). See also Martin Heidegger, Albert Hofstadter trans, Language, in Poetry, Language and Thought 187, 208 (Harper \& Row, 1971) ("[E]veryday language is a forgotten and therefore used-up poem, from which there hardly resounds a call any longer."); Friedrich Nietzsche, On Truth and Lying in an Extra-Moral Sense, in Sander L. Gilman, Carole Blair, and David J. Parent, eds, Friedrich Nietzsche on Rhetoric and Language 246 (Oxford, 1989) (stating that language tends to reify metaphors, suppressing differences and "leveling" the unique).

230 Schauer, Playing by the Rules at 56-60.

231 Id at 100-102. 
into account all the relevant factors, (2) are not capable of making an accurate decision using all relevant factors, (3) are untrustworthy or likely to be systematically biased, or (4) need to coordinate their action with others without the opportunity for communication. ${ }^{232}$ Although the resulting decisions are not perfect, they are better than they would be if the time-pressed, incapable, or untrustworthy decision maker had tried to take all relevant features into account. At times, humility requires that we accept the second-best.

Using Schauer's insights, a positive law theory of precedent would be most appropriate when the Court is setting out rules for inferior decision makers. Schauer employs the example of police officers, who must make quick decisions based on imperfect information, and who, because of their institutional position, may have biases that are difficult for them to counteract. ${ }^{233}$ Police officers should therefore only be held to knowledge of those Court-enunciated positive law rules in effect at the time of their conduct.

Qualified immunity law reflects this principle. Police officers are liable only for violations of clearly established constitutional rules. ${ }^{234}$ In this area, the Court has employed a positive law approach to determine which rules are "new," requiring officers to conform only to those rules clearly articulated by the courts. The existence of conflicts among lower courts is usually enough evi-

232 Id at 137-66. Schauer points out that the same premises are used for slippery-slope arguments. The idea that the proper decision in one case will "set a bad precedent" for future cases assumes that future decision makers will be unable to see the distinction between the present (desirable) case and the future (undesirable) case that is so apparent now. If the future decision maker is in the same position as the present decision maker, the slippery slope argument is weaker, if not absurd. Why should I do an injustice now to avoid an injustice later? When will justice be done, if not now? Compare Lewis Carroll, Through the Looking-Glass 72 (Random House, 1946):

"You couldn't have it if you did want it," the Queen said. "The rule is, jam tomorrow and jam yesterday-but never jam to-day."

"It must come sometimes to 'jam to-day," Alice objected.

"No, it can't," said the Queen. "It's jam every other day; to-day isn't any other day, you know."

${ }^{233}$ Schauer, Playing by the Rules at 150 (cited in note 172).

${ }_{234}$ See Harlow v Fitzgerald, 457 US 800, 818 (1982). Harlow eliminated any need for an officer to prove subjective good faith in order to be protected by immunity. Instead an officer would be held to the law that he could reasonably be expected to know-the law "clearly established" at the time an action took place. The Court had earlier made clear that police officers should not have to "predict" Supreme Court decisions in order to be immune from suit. Pierson v Ray, 386 US 547, 557 (1967). See also Graham v Connor, 490 US 386, 396-97 (1990) (" $[$ P]olice officers are often forced to make split-second judgments-in circumstances that are tense, uncertain, and rapidly evolving .... "). 
dence that a constitutional right is not clearly established; offcers are not generally expected to analogize from one area of the law to another ${ }^{235}$ or to look to state law or isolated lower court decisions outside their own jurisdictions. ${ }^{236}$ The Court's judgment that the mere existence of doctrinal conflict among the courts determines that a right is not "clearly established" is not only consistent with a positive law approach but also sensible, since police officers are in a worse position to interpret the law than judges.

When decision makers are not under extreme time pressure or other debilities, however, the Court's standard for precedent should not be based on positive law principles. Indeed, if state courts are only to follow the rules as articulated by the Court, the Court is implicitly assuming that state courts have less time, are less able, or are more biased than the federal courts-assumptions the Court has recently disavowed. ${ }^{237} \mathrm{Em}$ ploying a positive law approach to precedent with respect to state

${ }_{235}$ Compare the majority opinion's analysis in Procunier $v$ Navarette, 434 US 555, 562-65 (1978) (finding no clearly established First or Fourteenth Amendment prohibition on seizing prisoners' mail), with that of the dissent. See id at 573-74 (Stevens dissenting) (arguing that prison officials should have known that some of an inmate's mail involved legal communication, and that seizing it therefore violated the established right of access to courts). See also Davis $v$ Scherer, 468 US 183, 192 n 10 (1984) (finding no established right for a civil servant to receive a formal hearing before termination; prior case law required only "some kind of hearing"); Mitchell v Forsyth, 472 US 511, 530-35 (1985) (finding qualified immunity warranted since the law concerning warrantless wiretaps by executive officials was conflicting and uncertain at time the wiretaps were authorized); Anderson $v$ Creighton, 483 US 635, 640 (1987) ("The contours of the right must be suffciently clear that a reasonable officer would understand that what he is doing violates that right.").

${ }^{236}$ Consider Navarette, 434 US at 565 (stating that due to a conflict among circuit courts, a right could not be said to be "clearly established"); Fitzgerald, 457 US at $818 \mathrm{n}$ 32 (declining to decide whether lower court opinions would be relevant); Davis $v$ Scherer, 468 US at 195-97 (For purposes of overcoming qualified immunity, the existence of a state regulation designed to safeguard a constitutional right does not alone show that right was clearly established.). Lower courts have generally not found a "clearly established" right in cases in which the Supreme Court has not spoken and where there are conflicting cases in the lower courts. See generally Kinports, 33 Ariz L Rev at 140-48, 156-57 (cited in note 6), and cases cited therein.

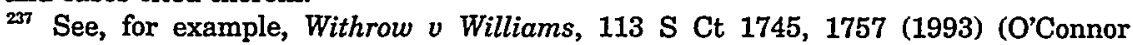
concurring in part and dissenting in part) (" $[S]$ tate courts have primary responsibility for enforcing constitutional rules in their own criminal trials."); Keeney $v$ Tamayo-Reyes, 112 S Ct 1715, 1719 (1992) (State courts have a "coordinate jurisdiction" with federal courts and should be allowed to "correct [their] own errors in the first instance."); Kuhlmann $v$ Wilson, 477 US 436, 453 n 16 (1986) (opinion of Justice Powell, with three other justices concurring in this note) ("SS]tates possess 'primary authority for defining and enforcing the criminal law, and hold the initial responsibility for vindicating constitutional rights."); Miller $v$ Fenton, 474 US 104, 112 (1985) ("TT]he federal habeas court should, of course, give great weight to the considered conclusions of a coequal state judiciary."). 
courts is also in tension with the view of the states as "testing grounds" for the "percolation" of constitutional principles. ${ }^{238}$ If the lower courts are substantially less capable than the Court of thinking through the law, percolation will yield few insights. Justice Harlan put his finger on the problem, noting that holding lower courts responsible only for connect-the-dots jurisprudence reduces them to the "role of automatons."239 If the Court wishes to treat state court judges as equals, it must assume that they are capable of seeing all the relevant characteristics of a case that the Court itself recognizes.

At times, however, the Court has not treated state courts as equally qualified to judge and has reduced their discretion to make decisions that take all relevant factors into account. Miranda $v$ Arizona is the classic example. ${ }^{240}$ There, the Court took from the lower courts the right to determine whether a confession was truly voluntary. It established the "prophylactic rule" that any confession not prefaced by an explicit waiver of Fifth and Sixth Amendment rights is deemed involuntary. The Miranda Court did not rule on the merits of voluntariness, even though it acknowledged that voluntariness was the ultimate concern. $^{241}$ Instead, it established a bright-line rule that produced more error than competent all-things-considered judgments of voluntariness would have. ${ }^{242}$ As the Court's long discussion of interrogation techniques makes clear, the Court established this rule partly out of mistrust of police and lower courts' abilities to make adequate judgments of voluntariness. ${ }^{243}$ Believing that an all-things-considered judgment of voluntariness was too likely to be biased or incompetent, the Court preferred a less well-tailored positive law rule.

${ }_{238}$ See Johnson $v$ Texas, $113 \mathrm{~S}$ Ct at 2675 (O'Connor dissenting); Butler, 494 US at $430 \mathrm{n} 12$ (Brennan dissenting). But see Althouse, 1991 Wis $L$ Rev at $942 \mathrm{n} 65$ (cited in note 6) ("Law is not coffee and analogies to coffee-making technology may misleadingly suggest ways to improve lawmaking.").

${ }^{239}$ Mackey v United States, 401 US 667, 680 (1971) (Harlan concurring).

240384 US 436 (1966).

${ }^{241}$ Id at 457,468 (not inquiring into the actual voluntariness of the defendant's confession or the defendant's awareness of his or her rights).

${ }^{242}$ See Schauer, Playing by the Rules at 154 (cited in note 172) ("When rule-based decision-making is in place, the most noteworthy error is the failure on some number of occasions to make the best or optimal decision in the particular case."). Taking an admittedly relevant issue away from a state judge out of concern that it will not be given its proper weight is different than simply deciding that something the state judge thought was relevant was not. Nearly any appellate decision "takes issues" from state judges in the latter sense, but very few in the former.

${ }^{243}$ See Miranda, 384 US at 448-55. 
The positive law nature of the Miranda rule explains why it should not have applied retroactively. Though state judges cannot rely on any positive law statements by the Court, they can reasonably rely on their own role as judges. In a common law setting, state courts make all-things-considered judgments. They must use their own reason to analyze the differences and similarities between their case and prior cases. State judges should not, within this common law framework, ignore any relevant decision-making factors. When the Miranda Court took away state judges' power to make all-things-considered judgments of voluntariness, it did indeed disturb state courts' reasonable reliance interests-their reliance on a common law system of adjudication itself.

\section{LOOKING BEYOND TEAGUE}

In this Section I hope to show that there are other ways to achieve the Court's stated goals of respecting state reliance and establishing finality in habeas cases without the double-talk of Teague. In doing so, I do not question these goals, although as many others have observed, they may be open to serious question. ${ }^{244}$ Instead, I aim only to envision habeas corpus free of "new rules." Three possibilities come to mind. The first simply accords state adjudications res judicata effect on habeas. The second looks to actual, reasonable reliance of those entitled to rely. The third and most promising simply excises Teague-type analysis from existing doctrine.

\section{A. Res Judicata for State Court Adjudications}

The suggestion that state court judgments be accorded some form of res judicata effect on federal habeas requires a reconsideration of whether reliance is really the issue. At least three members of the Court believe it is not. In West, Justices Thomas and Scalia, along with Chief Justice Rehnquist, expressed their sympathy with the idea that habeas corpus should be an extraordinary remedy, reserved only for claims that, through no procedural default of the petitioner, have not been "fully and fairly" adjudicated by the state courts. ${ }^{245}$ This trio would reserve habeas corpus for claims by, for example, pre-trial detainees, defendants whose trials were dominated by mobs or infected by cor-

24 See the commentary cited in note 6.

245 West, $112 \mathrm{~S} \mathrm{Ct}$ at 2489-91. 
ruption, and political prisoners who have had no trial. This revision of habeas law does not ask whether states reasonably relied on prior law; it straightforwardly defers to state courts by giving them the last word in most instances. While this deference would work a drastic change in habeas corpus law, it does have the virtue of honesty. Teague, while leading in the same direction, does so by way of the destructive, and perhaps disingenuous, inference that all decisions based on analogical reasoning violate reasonable reliance interests.

A related suggestion, which would also severely limit the availability of habeas corpus relief, is that Congress enact a statute of limitations for federal habeas corpus claims. ${ }^{246}$ Bills pending in Congress now codify Teague by specifying that "all claims shall be governed by the law as it was when the petitioner's conviction became final" except for intervening decisions that establish "fundamental" constitutional rights. ${ }^{247}$ A better approach would avoid the Teague quandary by establishing that a petitioner should receive the benefit of new rules enunciated between the time her state conviction was final and the conclusion of habeas corpus review.

\section{B. Actual Reliance}

The second possibility, stressing actual reliance, is inspired by Harper $v$ Virginia Dept. of Taxation, a case concerning the retroactive effects of invalidating a tax scheme. ${ }^{248}$ Despite the remaining disagreements conveyed in separate and dissenting opinions in that case, the Court appears to be converging on a consensus approach to civil retroactivity that might also be applied in the context of Teague. In Harper, as in the plurality opinion in Beam, ${ }^{249}$ the Court distinguished between addressing

${ }^{246}$ Both 1993 S 1441 (sponsored by Senator Biden) and 1993 S 1657 (sponsored by Senator Specter) would establish a filing deadline for habeas corpus relief of 180 days from the time conviction is final on direct review, or after state habeas proceedings where applicable, unless the state has not provided counsel. See The Habeas Corpus Reform Act of 1993, S 1441, 103d Cong, 1st Sess (Aug 6, 1993), in 139'Cong Rec 10927 (Biden); A Bill to Enforce the Fourteenth Amendment and to Reform Habeas Corpus, S 1657, 103d Cong, 1st Sess (Nov 10, 1993) (Specter).

${ }^{247}$ See 1993 S 1657. See also 1993 S 1441 ("The Court shall not announce or apply a new rule to grant habeas corpus relief.").

$248113 \mathrm{~S}$ Ct 2510 (1993). In Harper, the Court refused to return to the selective prospectivity of Linkletter and Chevron Oil Co. (its civil side-kick); instead the Court mandated retroactive application of the rule applied to the parties in the case to other cases still open on direct review.

${ }^{249}$ James B. Beam Distilling Co. $v$ Georgia, 111 S Ct 2439 (1991). 
retroactivity as a choice-of-law question and addressing it as a choice-of-remedy question. ${ }^{250}$ In the retroactivity context, "choice of law" refers to the choice between the law of some earlier time and the law as it now stands. "Choice of remedy" refers to the choice between redressing the wrong or denying redress on the ground that the offending party reasonably relied on prior statements of law.

In both Harper and Beam, the Court declined to decide the retroactivity issue as a choice-of-law question, thereby refusing to divide decisions into "new ones" and "old ones." The majority of the justices, while leaving open the possibility that a law could apply only prospectively, were wary of endorsing such a possibility. Instead, they preferred an approach that would temper the practical effects of retroactivity as a matter of remedy. They would acknowledge that the new law applied to the parties, but would take the actual reliance of parties into account in devising a remedy. ${ }^{251}$ Even Justice O'Connor, who argued strenuously in her dissents that retroactivity should be a choice-of-law issue, agreed that equity could come into play at the remedy stage. ${ }^{252}$ The disadvantage, of course, to considering reliance at the remedial rather than at the choice-of-law stage is that such reliance must be actual, not hypothetical. Therefore, reliance must be determined on a case-by-case basis.

In the Teague cases, in contrast, the Court has decided retroactivity as a choice-of-law matter. While it claims to be concerned with validating the reasonable reliance of state courts on existing precedent, ${ }^{253}$ the Court has not examined the law the state court actually cited, but has instead constructed its own version of the law that the state court might have relied upon. Detrimental reliance is essentially presumed once a decision is declared to be "new."

Nor has the Teague Court looked to the practical effects on the states of making its decisions retroactive. If actual reliance were the test, as in the tax cases, the Court would have to return to Linkletter's pragmatism and look closely at how seriously the states' criminal justice systems and community safety would be compromised by requiring a particular decision to apply retroactively.

251 Harper, $113 \mathrm{~S}$ Ct at 2519-20.

252 See id at 2536-37 (O'Connor dissenting).

253 See Butler, 494 US at 414; Parks, 494 US at 488. 
By analogy to the tax cases, other commentators have argued that the Teague cases might be approached as involving questions of remedy rather than substantive law. Professors Fallon and Meltzer have advocated such an approach, arguing that Article III concerns would not prevent the Court from announcing a new rule of criminal procedure, yet declining to apply it to the case at bar. ${ }^{254}$ Their approach, however, retains a "choice-oflaw" element; reliance would not be considered unless a rule were "new."255

Besides the questions raised by Article III, an actual reliance approach in the Teague context faces the further difficulty in that state courts can rarely be shown to rely reasonably on the Supreme Court's statements. Because state courts are usually in just as good a position to know all the reasons, principles, and analogies to be drawn from precedent as is the Supreme Court, they may not rely on the "positive law" in the Supreme Court's cases. They must judge for themselves, even at the risk of being reversed. The Court's proposition that reasonable disagreement

${ }_{254}$ See Fallon and Meltzer, 104 Harv L Rev at 1797-1805 (cited in note 6). Yet Justice Scalia has suggested that allowing the declaration of the law without giving it mandatory, coercive effect in the remedy would violate Article III's constraint that courts only decide actual cases or controversies. Beam, 111 S Ct 2450-51 (Scalia concurring); Harper, $113 \mathrm{~S}$ Ct at 2520-24 (Scalia concurring). Compare Lujan v Defenders of Wildlife, 112 S Ct 2130, 2136, 2140-42 (1992) (plurality opinion by Scalia) (To meet the standing requirement, a party must show that her injury can be directly redressed by a favorable judgment.); Franklin v Massachusetts, 112 S Ct 2767, 2787-88 (1992) (Scalia concurring in part and in the judgment) (same). This was also the reason given for selective prospectivity in Stovall $v$ Denno, 388 US 293, 301 (1967), and for making "newness" a threshold question in Teague, 489 US at 300 .

While I must leave a careful analysis of Article III to others, as it would blur my focus here, Justice Scalia's strong view of Article III is idiosyncratic at the least. Even if one views Article III as constitutionalizing a common law understanding of adjudication, common law courts have always separated the choice-of-law question from the remedial question. For example, they have frequently declared the rights of parties while allowing only nominal damages. See Beam, $111 \mathrm{~S} \mathrm{Ct}$ at 2443 (separating choice-of-law from remedial questions). See also Teague, 489 US at 318-19 (Stevens, concurring in part and in the judgment) (advocating an approach similar to "harmless error" analysis; "newness" should not be a threshold question, but rather an issue to be determined during remedial inquiry). Compare Farrar $v$ Hobby, 113 S Ct 566, 573-74 (1992) (awarding nominal damages produces a sufficient change of legal status to count as a remedy in federal court).

${ }^{255}$ See Fallon and Meltzer, 104 Harv L Rev at 1796 (cited in note 6) (defining "new" as slightly narrower than not "clearly foreshadowed") As I have argued, merely softening the new rule test will not establish a bright line, as long as state courts remain free to reinterpret and distinguish the holdings of precedents (as they should be in a common law setting). What is or is not clearly foreshadowed will depend upon how one characterizes the material facts and results of prior decisions. Moreover, the Court will still be put in the position of characterizing its decisions on the merits as "not clearly foreshadowed," even after the Court has taken pains to show how they are rooted in precedent. 
can generate reasonable reliance has it backwards: if the disagreement is truly reasonable, reversal is for that very reason not surprising.

One example, however, of when state courts could be said to reasonably rely on prior precedent is Miranda. As explained earlier, when the Supreme Court treats state courts as inferior decision makers and establishes positive law rules that block state judges' consideration of all relevant decision factors, states may claim reasonable reliance on the previous law, because states are entitled to assume they may use their best judgment in applying the law. Miranda-like rules should not be retroactive because they shift the adjudication paradigm from common law to positive law. State courts should be entitled to assume that they are equal partners in a common law enterprise, at least until the Supreme Court says otherwise. The state courts cannot be expected to anticipate their own institutional incompetence.

On this view, all of the decisions after Teague should have been applied retroactively. In all these cases, the Court decided the same question the state court had decided; it did not take questions away from the state courts out of a lack of trust that they would accurately weigh all the relevant factors. As the disagreement in these cases was a reasonable one among reasonable judges, within the common law paradigm there could have been no reasonable reliance by state court judges. ${ }^{256}$

This distinction may not, however, be as clear in other cases. For example, is Mapp $v$ Ohio's exclusionary rule ${ }^{257}$ a merits ruling about the proper sanction for Fourth Amendment violations, or an administrative ruling about the competence of state courts to fashion appropriate sanctions for violations by state actors? Batson $v$ Kentucky ${ }^{258}$ presents another hard case-did the Court establish a substantive federal rule about what counts as prima facie evidence of discrimination, or question the state court judge's ability to evaluate properly the state prosecutor's motives in striking a juror?

${ }^{256}$ It is important to recall here that the fact that the Court should have reached the merits in all the Teague cases does not mean that all the petitioners would have been entitled to relief. Only the petitioners in Sawyer and Butler, who relied on cases decided after their convictions were final, would have had further proceedings. The petitioner in Graham would have lost on the merits, as the Court's later case, Johnson v Texas, made clear. And judging by the tone of the opinions, it is unlikely that Taylor or Parks would have succeeded, either.

257367 US 643 (1961).

258476 US 79 (1986). 
To avoid these difficult inquiries into the reasonableness of state-court reliance, one is tempted by the pragmatic solution that the Court should simply ignore the reasonableness of a state's reliance and instead look to the actual effects of retroactive application. This approach does not solve the problem, however, because the Court would still have to consider a state's good faith. Otherwise, the states that can claim to be most disadvantaged by the retroactive application of constitutional decisions may be the states that have been least diligent in safeguarding constitutional guarantees. And federal court inquiry into state court good faith is perhaps more demeaning and intrusive than review on the merits. ${ }^{259}$

\section{Excising Teague}

A final, simpler approach to remedying the Teague problem would avoid the complications of determining actual reliance on the Court's prior statements while leaving the Court's habeas corpus doctrine relatively intact. The Court could simply eliminate Teague. To begin with, criminal procedure is changing less rapidly now; states are expected to apply the Supreme Court's interpretation of the Bill of Rights to their criminal defendants. Few cases today could have the disastrous effects on state institutions that, for example, applying Miranda retroactively would have occasioned. Recall that the Court did not worry about retroactivity until 1965. Perhaps it need not worry now.

Moreover, since Justice Harlan first voiced concern with habeas finality, the Court has responded to that concern directly. Justice Harlan was troubled primarily by the forgiving standard of Fay $v$ Noia, which allowed petitioners on federal habeas to raise any claim that had been procedurally defaulted in the state courts-raised improperly or not raised at all-so long as the petitioner had not deliberately bypassed the state courts to assert the claim in federal court. ${ }^{260}$ In Wainwright $v$ Sykes, however, the Court replaced Noia's deliberate bypass standard with a requirement that a petitioner show cause for the default and prejudice to his case before a defaulted claim could be heard in federal court. ${ }^{261}$ That change alone might have satisfied Justice Harlan,

259 See Friedman, Habeas and Hubris, 45 Vand L Rev at 815-16 (cited in note 6) (arguing that a deterrence theory of habeas corpus flies in the face of the federalist philosophy of respect for state institutions, as does rehashing guilt determinations).

260372 US 391, 427-28, 438 (1963); id at 448-76 (Harlan dissenting).

261 Wainwright $v$ Sykes, 433 US 72,87 (1977). 
Teague's intellectual father. He noted that the lack of finality of habeas petitions was less troubling before Noia established a lenient standard for forgiving state procedural defaults, allowing prisoners to petition based on theories they had not raised in their initial state appeals. ${ }^{262}$ More recently, in McCleskey $v$ Zant, the Court imposed the cause-and-prejudice standard on those seeking to file second federal habeas petitions, making it very unlikely that a petitioner could repeatedly relitigate his conviction years later. ${ }^{263}$ These rules should greatly alleviate any concern that state institutions ought not be forced to gather forgetful witnesses and moldering evidence for a second trial at every drop of a habeas hat. ${ }^{264}$

The problems that beset Teague also suggest changing another habeas rule: under current doctrine, newness is an excuse for failing to raise a claim in state court. In Reed $v$ Ross, the Court excused a litigant's failure to raise "a constitutional issue reasonably unknown to him" because it then had "no reasonable basis" in existing law. ${ }^{265}$ The no "reasonable basis" standard was tied to the standard of newness in the pre-Teague retroactivity cases, so that counsel would not be responsible for anticipating circumstances in which the Court made a "clear break" with prior precedent by overruling a prior decision or by overturning a "longstanding and widespread" practice expressly approved by the lower courts. ${ }^{266}$

262 Desist $v$ United States, 394 US 244, 261 (1969) (Harlan dissenting).

${ }_{263} 499$ US 467,468 (1991) (holding that a second-time petitioner must show cause and prejudice for failing to raise a claim in the first writ, unless a "fundamental miscarriage of justice" would result).

${ }_{264}$ While these procedural rules may insulate state decisions from review, they do not necessarily alleviate the habeas corpus workload of federal courts, which have to spend their time determining the boundaries of cause and prejudice instead of deciding the merits.

205468 US 1, 14-15 (1984).

266 Id at 17, quoting United States $v$ Johnson, 457 US 537, 551 (1982).

Whether counsel would be expected to challenge a practice "arguably [] sanctioned in prior cases" was a "more difficult question," depending on "how direct [the] Court's sanction of the prevailing practice had been, how well entrenched the practice was in the relevant jurisdiction at the time of defense counsel's failure to challenge it, and how strong the available support is from sources opposing the prevailing practice." Ross, 468 US at 17-18.

Ross had been convicted under jury instructions that placed the burden on him to prove absence of malice, an element of the crime of murder. Id at 3 . Such instructions were much later held unconstitutional, because they did not place upon the government the burden of proving each element of the crime beyond a reasonable doubt. See Mullany $v$ Wilbur, 421 US 684, 704 (1975), citing In re Winship, 397 US 358, 364 (1970). Ross, however, did not challenge his instructions on appeal. 468 US at 7. 
It should be clear that Ross involves the same problematic analysis as in Teague. Like a court applying Teague, a court applying Ross must adopt something of a split personality to determine which of its decisions are new and which are not. As with Teague, Ross requires a court to consider whether its previous decisions, which purport to rely on precedent, are nonetheless "clean breaks" with precedent. This double standard makes Ross troubling for the same reasons as Teague is troubling. ${ }^{267}$

Thus, the "newness" of a claim should not be good cause for failing to raise it in state court. This change would be consonant with the presumption of common law adjudication that the tools for constructing the reasonable argument or the persuasive analogy are already available. Even in the extreme situation of overruling precedent, it is overruled for reasons, and those reasons are usually provided by the lawyers in the first instance. ${ }^{268}$

The Court excused him from his default. Not only had the relevant Supreme Court decisions not yet been decided, but the argument had never been made in the North Carolina courts, and only one Federal Court of Appeals and the Superior Court of Connecticut had held it unconstitutional to require a defendant to disprove an element of a crime. Id at 18-19.

Then-Justice Rehnquist dissented, joined by Chief Justice Burger and Justices Blackmun and O'Connor. He argued that the constitutional basis of the reasonable doubt standard had been long settled, and the jury instruction cases upon which Ross wished to rely had likewise been simple applications of that settled law. Id at 22-26 (Rehnquist dissenting). He noted that the Court itself characterized its holdings in those cases as already "settled by a long line of earlier decisions," and "well established." Id at 23 (Rehnquist dissenting). His ironic conclusion was that "it seems, lawyers are not required to reason in quite the same manner as judges do.... Either one or the other of these modes of reasoning, it seems to me, must be wrong." Id at 26 (Rehnquist dissenting). Compare Butler, 494 US at 415 ("[T]he fact that a court says that its decision is within the 'logical compass' of an earlier decision, or indeed that it is 'controlled' by a prior decision, is not conclusive for purposes of deciding whether the current decision is a 'new rule'.....) (per Rehnquist).

${ }^{267}$ Ross has not been much discussed or widely applied primarily because its holding was largely eviscerated by Teague: If a claim is new enough to constitute cause under Ross, it is also new enough to be unjusticiable under Teague. See Marc M. Arkin, The Prisoner's Dilemma: Life in the Lower Federal Courts After Teague v. Lane, 69 NC L Rev 371, 407-08 (1991); Hopkinson v Shillinger, 888 F2d 1286, 1289-90 (10th Cir 1989). But see Hoffmann, 1990 BYU L Rev at $212 \mathrm{n} 126$ (cited in note 6) (arguing that there should be a difference between which claims lawyers should reasonably make and which claims a state judge should reasonably adopt).

263 Compare Eisenberg, The Nature of the Common Law at 36 (cited in note 13):

[A] Imost any rule employed in a common law decision is new in the sense that the court must choose in every case whether to apply, extend, reformulate, or radically reconstruct relevant doctrinal propositions. As long as the courts follow a replicable process this feature of the common law is not unfair. Since every member of society has reason to know that the society's legal rules will reflect policies, and reason to know that a policy has the requisite social support, neither the policy nor judicial action reflecting the policy should normally involve unfair surprise. 
When a doctrine becomes unreasonable, or is unreasonable as applied in a particular situation, a good attorney should not rely on it. ${ }^{269}$

So, adhering to the common law view that the relevant legal material already exists means that neither judges nor lawyers may reasonably rely on positive law rules. Judges and lawyers act within the same practice community; both know how to argue about "material" differences. They do not need a case on point to find a distinction with a difference.

The Court should therefore abandon both Teague and Ross. Newness should neither excuse state procedural default nor bar review in federal court. ${ }^{270}$ Along with the Court's other habeas retrenchments, this result would protect states from relitigating stale claims. Without Teague, the Court may still, in rare cases, overrule a precedent upon which state actors relied. However, without Reed, a petitioner cannot bring the claim on habeas unless he brought it first in state court, unless the state has decided to waive the default. And as long as the states had the opportunity to address the claim, much of the Court's concern with comity will be served. First, given the initial opportunity to redress the petitioner's complaint, state courts may provide the requested protections in-house. Second, prior adjudications will give the state courts the chance to express their reasons for denying the requested protections and to articulate their understanding of the law.

${ }^{269}$ See Rodriguez de Quijas v Shearson/American Express, Inc., 490 US 477 (1989). Lawyers had argued that a Supreme Court case on point was obsolete, and lower courts had agreed. Though affirming the lower court decision and administering the official coup de grace to the "incorrect" precedent, the Court complained that the lower courts should have left it for the Court to overrule its own case. Id at 484 . See also Eisenberg, The Nature of the Common Law at 110 ("The coupled values of protecting justified reliance and preventing unfair surprise are also normally no better served by preserving a jagged doctrine [a doctrine that is socially outmoded and riddled with exceptions] than by overruling it.").

270 I would not suggest eliminating the exception to the cause-and-prejudice standard for facts that were reasonably unavailable. See, for example, Amadeo $v$ Zant, 486 US 214, 222-24 (1988). It is, of course, open to the states to take a more liberal view of procedural default. If the states do not have a doctrine of procedural default, then there is no "interest in finality" to respect-instead, the states have made the decision that they want convictions reexamined. Eliminating Teague and Ross would still allow the states to decide the fate of their own cases consistent with principles of federalism, just as Teague doctrine now allows states to waive the Teague bar. See Collins $v$ Youngblood, 497 US 37, 41 (1990).

I am also assuming the retention of the existing doctrine that state procedural default may be waived when a defendant makes the requisite showing of actual innocence. See Murray v Carrier, 477 US 478, 496 (1986). 


\section{CONCLUSION}

In sum, habeas corpus relief can be limited without perpetuating Teague's contradictory and dangerous jurisprudence. Simply eliminating Teague would not be unworkable or unfair to state courts. As explained above, state courts should have the first opportunity to judge their cases, but they have no reasonable expectation that they will not be reversed. Often enough, they can guess the potential grounds of their reversal. It is true that the result in a particular case is rarely so clear that there is not room for reasonable disagreement, but the reasonableness of the disagreement belies the notion that reversal is an unfair surprise.

On the other hand, to allow Teague to stand would be to call into question common law adjudication itself, requiring the Court to second-guess its own analysis of precedent while explaining that "following" precedent is not much more than a noble lie. This self-destructive legal analysis is too high a price to pay for habeas reform. Surely something judges say matters. 